From Plan to Market

Patterns of Transition

Martha de Melo

Cevdet Denizer

Alan Gelb
Among the findings from this analysis of patterns of transition: Liberalization is essential to stabilization despite an initial spurt in prices. And economic recovery depends on the duration as well as the intensity of liberalizing interna! and external markets and facilitating private sector entry.

The World Bank 


\section{Summary findings}

In analyzing the transitional experience of countries in Central and Eastern Europe(CEE) and the former Soviet Union (FSU), de Melo, Denizer, and Gelb find strong common parterns for countries at similar stages of reform despite differences in initial conditions. To establish rankings, the authors create a reform index combining the intensity and duration of economic liberalization.

Freeing domestic prices is one element of reform captured by the index; it was needed to enable governments to cut subsidies and restore macroeconomic balance. Other dimensions of reform captured by the index are liberalization of external trade, including foreign currency convertibility, and facilitation of private secror entry through privatization of state enterprises and improvements in the environment for private sector development. Some countries moved faster on reform than others, and one major reason appears to have been the pace of political liberalization.

Liberalization has encouraged capital and labor to reallocate from industry toward services, many of which were previously repressed; and the repressed sectors fueled the return to positive growth in fast reformers. For slow reformers, the main problem in achieving stabilization has been the continued monetization of fiscal and quasi-fiscal deficits, associated with attempts to maintain employment in the old system.

Among the policy implications:

- Stabilization is a priority for the resumption of growth, and this requires extensive liberalization.

- Stabilization is made difficult by output contractions in the early stages of liberalizarion (they reduce tax revenues and raise claims on fiscal resources to cushion the effects), by limited external financing, and by very large depreciarions of the real exchange rate.

- Contrary to previous suggestions, there is no evidence that a slower pace of reform strengthens the fiscal position of slow reformers; their consolidated fiscal and quasi-fiscal deficits are quite high.

This paper - a product of the Transition Economics Division, Policy Research Department - is part of a larger effort in the department to synthesize the adjustment experience of countries in transition from socialism to a market economy. Copies of the paper are available free from the World Bank, $1818 \mathrm{H}$ Street NW, Washington, DC 20433. Please contact Christopher Rollison, room N9-054, telephone 202-458-4768, fax 202-522-1151, Internet address crollison@worldbank.org. January 1996. (63 pages)

The Policy Research Working Paper Series disseminates the findings of work in progress to encourage the exchange of ideas about development issues. An objective of the series is to get the findings out quickly, even if the presentations are less than fully polished. The papers carry the names of the authors and should be used and cited accordingly. The findings, interpretations, and conclusions are the authors' own and should not be attributed to the World Bank, its Executive Board of Directors, or any of its member countries. 


\section{FROM PLAN TO MARKET: PATTERNS OF TRANSITION}

Martha de Melo

Cevdet Denizer

Alan Gelb

Transition Economics Division

Policy Research Department

World Bank 



\section{FROM PLAN TO MARKET: PATTERNS OF TRANSITION ${ }^{1}$}

\section{INTRODUCTION}

The transition from a planned economy to a market economy involves a complex process of institutional, structural and behavioral change. Formerly communist countries have moved along this transition to varying degrees. ${ }^{2}$ This paper places these countries into a comparative perspective. It emphasizes the cornerstone of the early reforms-economic liberalization, for which an index is developed-and its interaction with growth and inflation: how do these outcomes relate to progress with reform? It also considers macroeconomic and sectoral patterns underlying these interactions.

The findings here help to explain two paradoxes of transition. One is that the attempt to maintain employment and output by fiscal and quasi-fiscal transfers to enterprises results in larger output declines than a policy of hard budget constraints introduced along with economic liberalization. The other is that the liberalization of prices results in lower inflation than continued price controls. In both cases, liberalization leads to stabilization in a way that is not self-evident to policy-makers accustomed to socialist pricing and output conventions.

The core countries analyzed are 26 in Central and Eastern Europe (CEE) and the Former Soviet Union (FSU), plus Mongolia (which, as the so called "16th Republic," is included in the FSU group). China and Vietnam are also included for comparative purposes, although these countries are distinctive in many respects. ${ }^{3}$ The period covered is 1989 through 1994 . The starting point is the last year before the initial postcommunist transitions, although Poland, Hungary, the former Yugoslavia and China had previously initiated significant reforms and other countries had also taken some reform steps.

What are the essential commonalities at the macroeconomic and broad sector level? Section II highlights four stylized features of the socialist legacy and predicts corresponding outcomes from transition. ${ }^{4}$ Such changes are stimulated by a wide range of policy reforms

\footnotetext{
I Stoyan Tenev developed the switching regression technique used in this paper. We appreciate comments on the economic liberalization index by World Bank staff, and comments on other aspects of the paper by Lescek Balcerowitz, Stanley Fischer, Wafik Grais, Arvo Kuddo, Costas Michalopoulos, Branko Milanovic, Randi Ryterman, Tevfik Yaprak, and participants in the First Dubrovnik Conference on Transitional Economies, where the paper was presented in June 1995.

2 See Fischer and Gelb 1991 for an early discussion of the elements of the transition process and Kornai 1993a for a discussion of the multi-faceted problems associated with the "transformational recession."

3 Transition countries in South Asia, Africa, and Latin America are not addressed here, nor are the former GDR, rump Yugoslavia and Bosnia.

4 An important feature not mentioned is the widespread availability of basic human needs (education, health services and housing), associated with a more equal distribution of income than in capitalist countries (Milanovic 1995). The transition has been accompanied by increasing inequalities in money income and a deterioration in social services, but these issues go beyond the scope of this paper.
} 
collectively referred to as "economic liberalization;" but a summary measure is needed to link liberalization to macroeconomic performance. In Section III, we define a composite index which takes into account three dimensions of liberalization: (i) internal markets, (ii) external trade, and (iii) facilitation of private sector entry. ${ }^{5}$ Countries are ranked on the depth of these policy reforms in each of six years of transition, 1989-94. Country classification is then based on cumulative liberalization-reflecting duration as well as depth of reform-because structural and institutional adjustment takes time, even when policy change itself is rapid. Countries are placed in four reform groups, plus a "war" category for those whose economies have been severally affected by conflict.

Section IV analyses cross-country evidence on the interactions between liberalization, economic growth (or contraction) and inflation. Section $\mathrm{V}$ extends this by looking at the time profile of the transition experience. It first traces the experience of each reform group over the period. It then estimates a regime-switching equation to provide a profile for reformers and nonreformers. Section VI considers macroeconomic and sectoral patterns underlying the (rather strong) relationships derived above.

Section VII addresses the deeper question: "what accounts for economic liberalization?" Many characteristics, including history and culture affect policy choice, but here we look at politics. For ECE and FSU, a close relationship is found between economic liberalization and political reform, as given by a widely used index of political freedom, and this is assessed. Section VIII summarizes main conclusions and their implications for some policy debates.

\section{Data Limitations}

Before proceeding with any empirical paper on transition, one should note very serious data weaknesses. ${ }^{6}$ Under socialism, output of state enterprises was often exaggerated, while during the transition, output-and especially the size of the private sector-tends to be underreported, sometimes by large margins according to recent studies. ${ }^{7}$ Stockbuilding is frequently mismeasured. Inflation is also difficult to measure, with sharp changes in the quality and composition of goods and a base period characterized by serious shortages at fixed official prices. Problems estimating deflators means that "real" wages are then hard to measure. Detailed reviews of individual countries suggest that official unemployment rates, which range from almost zero to 17 percent, reflect incentives to report as well as the actual level of unemployment. Trade and balance of payments data are difficult to interpret consistently over time in the transition from the planned trading system because of inconsistent bilateral exchange

\footnotetext{
5 EBRD 1994 provides a good overview of many dimensions of policy change and serves as a 1994 marker for the liberalization index developed here.

6 For more discussion, see EBRD 1994 and Balcerowitz and Gelb 1994 and references therein.

7 A separate problem is whether output is a useful welfare measure, since a proportion of its fall will involve the elimination of production that has little value in a market economy driven by consumer preference.
} 
rates used in CMEA trade and problematic intra-USSR trade data. Cross-border trade is now hard to monitor.

We have some idea of the likely direction of most statistical biases, but their extent may differ among countries. Balcerowicz and Gelb 1994 argue, for example, that underreporting of output is likely to be larger in radical reformers, where private activity is growing fastest. While this is not implausible, black markets thrive on pervasive regulation, and statistical systems have themselves adjusted less in certain slow-reforming countries (and also in war-torn countries), so that the opposite result could hold. ${ }^{8}$ We test the robustness of the results of the switching-regime equation in Section VI by simulating plausible adjustments for the underground economy. But given the more general uncertainties, the paper emphasizes broad trends and large observed differences, rather than fine ones.

\section{THE COMMON LEGACY AND ITS IMPLICATIONS}

The extent to which transition can be considered a common process depends on the relative strength of the common legacy of communism versus country-specific factors. Transition countries differed substantially in their initial conditions, which include the level of income and wealth, the nature and extent of economic distortions, and the level of institutional development. ${ }^{9}$ However, they also had a strong common legacy that can be characterized by four features:

- Macrobalance by direct control. Financial flows were the passive outcome of central directives that regulated credit and incomes. Financing of enterprises was set by a credit plan, taking into account investment targets, and implemented through the mono-bank financial sector. Surpluses were accumulated in large enterprises and were transferred to the budget to finance subsidies and transfers as well as direct expenditures, which accounted for up to 50 to 60 percent of GDP. Given fixed prices and consumption targets, wage control was the critical factor for the balance between output and demand. In the years prior to the collapse of the old regime, wage increases exceeded the ability of the economy to provide consumer goods, resulting in involuntary accumulation of financial assets, or repressed inflation.

- Coordination through plans. Economic activity was based on a central plan with quantitative output targets specified in physical units. Heavy industry was accorded priority over consumer goods, and service sectors were accorded low priority in the

\footnotetext{
8stimates of unrecorded economic activity exist for a number of countries but vary widely both between countries and, for individual countries, between sources. The difficulty in incorporating such estimates into growth rates is compounded by the lack of precise estimates of the size of unrecorded economies before transition.

9 See de Melo, Denizer, Gelb, and Tenev (1995, forthcoming) for an exploration of the nature and importance of initial conditions and other country-specific factors in the transition cxperience.
} 
allocation of resources. The matching of income and expenditures with physical targets was achieved through coordinated, economy-wide plans, such as the central plan for material products, the manpower plan, the credit plan, and the investment plan. Domestic trade was carried out by centralized organizations, and the CMEA (Council for Mutual Economic Assistance) system linked most CEE countries and Mongolia into the highly planned economy of the USSR. These practices were softened in "market socialist" countries, but even there discretionary ex post interventions by central authorities largely offset market forces.

- Little private ownership. With limited exceptions, property rights were exercised by the state, and private ownership was not allowed. The lack of a profit motive, arising from the absence of private ownership, adversely affected efficiency, and the prevalence of planned allocations meant that communist economies had relatively few small firms. ${ }^{10}$

- Distorted relative prices. Prices played an accounting role and were set in accordance with the central plan. Implicit prices of essentials-including housing, energy, transportation, education and medical care-were kept low, and land prices were essentially zero. ${ }^{11}$ Implicit trade margins were low, and prices of final goods failed to reflect differences in distribution costs.

\section{Table 1: From Plan to Market}

What happens when a planned economy with the above features is replaced by a market system with liberalized prices? ${ }^{12}$ Each of these features has its counterpart in systemic changes occurring during transition (Table 1):

- Macroeconomic destabilization. Initial price liberalization typically leads to subsequent price increases, especially if it is undertaken under conditions of repressed inflation. The immediate challenge for macroeconomic policy is then to slow the rate of price increase and reverse the inflationary expectations and flight from domestic financial assets that follow the initial price spike. This requires introducing hard budget constraints on enterprises while introducing well-targeted social expenditures, including unemployment benefits. But inflationary pressures may persist, if and when the government's traditional tax base is eroded due to: output losses mentioned below, further pressure on state enterprises' revenues due to their loss of a monopoly position, and difficulties in imposing payments discipline through a previously passive financial system.

\footnotetext{
10 For a comparison of industrial organization, see Ryterman 1994.

"Partly because of the suppression of prices in key nontraded sectors, the ratios of PPP-based GDP to exchange-rate based GDP tend to be high for communist countries. For discussion of China (where the ratio has been up to 8 to 1 ) see Gelb, Jefferson, and Singh 1993 and World Bank 1994.

12 Elements of an answer to this question appear in various works. See Berg and Sachs 1992, Berg 1993, Aghion and Blanchard 1992. Coricelli and Chadha 1993, Kornai 1993a, Ickes and Ryterman 1993, and Taylor 1994.
} 
- Output declines from disruptions in the coordinating mechanism. The sudden abolition of planning in a complex, highly interdependent economy can impair economic coordination, affecting both useful and unwanted production pending the establishment of a new, efficient system of market coordination. ${ }^{13}$ The resulting increases in transactions costs can be imagined as a negative supply shock to an economy-wide production function which is specified to include coordination activities (such as trade and payments) as an intermediate sector. How serious output declines actually are would depend on the degree of interdependence within the economy, the extent to which the planning system was disrupted, and the speed at which the new, market-based coordinating system develops. In some countries, where plan coordination began to deteriorate prior to price liberalization, costs may occur over many years. For example, in the FSU, the planning process deteriorated after glasnost and perestroika began to take hold in 1987.

- Output gains from private ownership and private sector growth. Efficiency gains come from the legalization of private ownership, which creates incentives to maximize returns; the establishment and enforcement of a legal framework to support private activities; and the facilitation of private entry. Much of the increased private sector output would be produced by smaller firms. In the long run, the movement from (inefficient) plan to (efficient) market should be equivalent to a positive supply shock, raising the efficiency of resource allocation and creating a burst of economic growth, as well as increasing the "utility" of output. The latter would be expected to rise as output increasingly reflects individual preference rather than the demands of a plan. ${ }^{14}$

- Microeconomic and sectoral reallocations. Microeconomic and sectoral reallocations occur in response to price changes resulting from liberalization and cuts in subsidies, as well as to changes in demand. Previously repressed sectors, notably energy and services, should expand and offset declines in industry-especially in defence-related industry, given substantial cuts in defence procurement-and agriculture, which was heavily subsidized in many countries. Expansion of previously repressed nontraded sectors, including real estate, occur despite large devaluations in exchange rates, which normally favor traded goods. Developments in the labor market would reflect the changes in the composition of sectoral output, and especially the growth of small private trade and transport activities.

\footnotetext{
13 Consider, for example, the case of the Kyrgyz Republic, which may have a comparative advantage in agriculture but has no institutional mechanism to allocate and recover agricultural credit. Other impediments to coordination have been introduced as a result of new national boundaries, which interfere with payments arrangements for the output from production monopolies now located abroad, or the allocation of previously centralized gas-pipeline capacity.

14 If the post-transition distribution of income were very undesirable, the social utility of output could of course be judged as inferior to an inefficient planned output bundle.
} 
These changes occur both as a result of disintegration of the old regime and in response to active measures of economic liberalization. An interesting question, that we address below, is to what extent transition can be considered a common process, and in particular to what extent differences in experiences with growth and inflation are associated with economic liberalization.

\section{COUNTRY EXPERIENCE WITH ECONOMIC LIBERALIZATION}

In order to explore the broad cross-country relationships between growth, inflation and liberalization, we construct an annual index of liberalization for the transition period starting in 1989. This index is then used to classify countries into reform groups, based on their cumulative experience with economic liberalization as of end-1994. Comparative analysis shows that recent experience with growth and inflation is broadly consistent within groups.

\section{Aggregate indicators}

Growth, inflation, and liberalization are defined as follows:

Growth is represented by annual changes in real, officially measured GDP.

Inflation is represented by average annual changes in the CPI. ${ }^{15}$

Liberalization is measured by an index of economic liberalization that has been constructed for purposes of the analysis below. An annual Liberalization Index (LI) is calculated for each country for each year over the 1989-94 period. It ranges from 0 to 1 , where 0 represents an unreformed, and 1 represents a basically-reformed, country. The LI is the weighted average (with weights of $0.3,0.3$., and 0.4 respectively) of 0 to 1 rankings of liberalization in the following three areas:

I - internal markets (liberalization of domestic prices and abolition of state trading monopolies) ${ }^{16}$

E - external markets (liberalization of the foreign trade regime, including elimination of export controls and taxes and substitution of low to moderate import duties for import quotas and high import tariffs; currency convertibility); and

\footnotetext{
15 Substantial cross-country variation exists in the behavior of different price indices. In Poland and especially Bulgaria, increases in the CPI have outpaced those in industrial prices, reflecting a sharp rise in the relative price of services, which was previously a suppressed sector. In Russia, on the other hand, price liberalization was followed by a sharp increase in the relative price of heavy industrial goods, probably reflecting strong monopoly power domestically reinforced by limited import competition due to a very depressed real exchange rate.

${ }^{16}$ Countries with an $\mathbf{I}$ rating near unity may still maintain price controls on a range of non-traded household essentials, in particular rents and household utilities.
} 
$\mathbf{P}$ - private sector entry (privatization of small-scale and large-scale enterprises and banking reform). ${ }^{17}$

The values assigned to these three areas in each year are shown for 28 transition economies in the Appendix, which also explains how the values are derived.

The weights used in aggregating the components of the index are notional estimates of the relative impact of $\mathbf{I}$ and $\mathbf{E}$, which represent liberalization through introduction of competitive, flexible-price markets, and $\mathbf{P}$, which represents liberalization through changing ownership of fixed assets. The effects of these components differ slightly, as mentioned below in the discussion of the growth and inflation equations.

In the analysis that follows, a Cumulative Liberalization Index (CLI) is defined to represent the duration as well as the intensity of reforms from 1989 onward. It is calculated as the sum of a country's LIs. The rationale for using the CLI is that, at any given moment, economic performance will not be determined by the degree of liberalization in that moment alone; it will also be shaped by institutional and other changes stimulated by prior policy reforms. CLIs for 1994 are shown in the Appendix and are used in Table 2 to rank CEE and FSU countries not affected by war into four reform groups, determined by natural breaks in the CLI values:

Group 1: advanced reformers (CLI > 3)

Group 2: (high) intermediate reformers $(2<\mathrm{CLI}<3)$

Group 3: (low) intermediate reformers $(1.3<\mathrm{CLI}<2)$

Group 4: slow reformers (CLI $<1.3$ )

Countries affected by war and the two East Asian countries are shown separately:

"War" countries include former Yugoslav and Soviet republics that have experienced major and persistent internal conflicts during 1989-94 or, in the case of Armenia and FYR Macedonia, conflict-related blockades. ${ }^{18}$

The macro and reform experiences of the East Asia countries, China and Vietnam, differ from those of CEE and the FSU. Although their 1993/94 LIs are lower than those of

\footnotetext{
17 The indicators used for $\mathbf{P}$ are proxies for opening up the economy to private sector development. They do not capture the overall quality of the legal and regulatory framework or the effectiveness of government in institution-building or in the implementation of reforms, but only because of the difficulty of developing comparative measures. Also, land privatization is not included; however, several countries (Romania, Armenia, Albania, and Lithuania) have privatized agricultural land, helping to stimulate agricultural growth.

is Georgia and Armenia were relatively advanced among FSU reformers, but have since used state controls to try to support their "war economies". For example, Armenia maintained state orders to ensure a supply of goods to barter with Turkmenistan for vital energy supplies. In regressions below, Moldova is included with the "war" countries for 1992.
} 
advanced reformers like Poland, their CLIs are quite high, reflecting their introduction of important reforms before many of the other countries covered here.

Before turning to an analysis of the interactions between growth, inflation and liberalization, we look more closely at the properties of the liberalization index. Figure 1a shows the evolution of means over the 1989-94 period, and Figure 1b shows the evolution of standard deviations. The means for $\mathbf{I}$ and $\mathbf{E}$ show large increases in 1991, reflecting reform in CEE countries, and in 1992, reflecting reform in FSU countries; the mean for $\mathbf{P}$ shows a more modest but steady increase over the whole period. Comparing means in 1989 with those in 1994, the most progress has been in the liberalization of internal markets and the least in private sector entry. Standard deviations for $\mathbf{I}$ and $\mathbf{E}$ peaked in 1991 and have since declined, especially for I, reflecting the fact that most countries had moved ahead on internal price liberalization by 1994, even though no country had fully liberalized prices. The standard deviation for $\mathbf{P}$ increases over time as privatization in some countries leaps ahead but lags in others.

\section{Figures 1a and 1b: Means and Standard Deviations of LI Components}

The three components of the liberalization index are also highly correlated with each other, suggesting that there is a high degree of complementarity in designing and implementing different types of reform and that any one component will perform almost equally well in regressions against growth and inflation. The correlation-as measured by the Pearson, or simple, correlation coefficient and the Spearman rank correlation coefficient-is somewhat higher between $\mathbf{I}$ and $\mathbf{E}$ than between either of these and $\mathbf{P}$. Pearson correlations are .93 (I and $\mathbf{E}$ ), .84 (I and $\mathbf{P}$ ), and .82 ( $\mathbf{E}$ and $\mathbf{P}$ ); Spearman rank correlations are slightly higher. As shown in the following matrix of (Pearson) correlation coefficients, the CLI is marginally more strongly associated with growth and inflation than the cumulative index of any one component (shown under I, $\mathbf{E}$ and $\mathbf{P}$ ):

\section{Matrix of Simple Correlation Coefficients ${ }^{19}$}

$\begin{array}{lcccc} & \text { I } & \text { E } & \text { P } & \text { CLI } \\ \text { AVGR } & .57 & .52 & .60 & .59 \\ \text { AVLIN } & -.72 & -.67 & -.73 & -.74 \\ \text { GR93/4 } & .72 & .69 & .67 & .73 \\ \text { LIN93/4 } & -.80 & -.75 & -.79 & -.81\end{array}$

\footnotetext{
19 AVGR is average real GDP growth and AVLIN is the average log of inflation over 1989-94; GR93/4 and LIN93/4 are the same variables for the period 1993-94.
} 
The CLI is constructed to reflect the six year period 1989-94, where the first year has historical significance for all CEE and FSU countries. A limitation on the time period is consistent with partial adjustment models, which show that the effect of reforms diminishes over long periods.

\section{GROWTH, INFLATION AND LIBERALIZATION}

Following the dissolution of the Council for Mutual Economic Assistance (CMEA) and the ruble zone, each country in the CEE and FSU has followed its own path to reform, with varying speed and intensity. Here, however, we explore the hypothesis that despite the diversity in country circumstances, simple relationships exist between real GDP growth and economic liberalization; inflation and economic liberalization; and growth and stabilization. The statistical analysis below suggests that variations in country experience during the transition are in fact strongly associated with liberalization and that the return to positive growth is associated with declines in inflation to double digits or less.

\section{Growth and liberalization}

The data in Table 2 on growth and cumulative output declines show systematic variation by reform group (based on unweighted averages). Although outputs initially fell, advanced reformers were stable or growing in 1993/94; maximum output declines were about 80 percent of those in 1989. High intermediate reformers lost about a third of their GDP, but most have also stabilized or returned to positive growth. The highest growth was in Albania, which has benefitted from high external financing, and together with Romania, strong agricultural growth. Low intermediate reformers have fared the worst so far, with continuing strong output declines through 1994. The slowest reformers have managed to somewhat retard their output declines, and Uzbekistan appears to have so far defied the general pattern by avoiding a major decline.

For the "war" countries, huge cumulative output declines (which, as shown below, have quite distinctive sectoral features) highlight the cost of war and associated economic blockades. At the other end of the spectrum, the East Asian experience has been one of continuous development; both China and Vietnam have experienced high growth since 1989.

\section{Table 2: Liberalization, Growth and Inflation}

The overall relationship between recent output growth and the CLI is shown in Figure 2 for the $20 \mathrm{CEE} / \mathrm{FSU}$ countries not affected by war. A simple quadratic relationship shows a positive association between growth in 1993/94 and the CLI. It suggests that over half the variation in real growth is associated with increases in economic liberalization, with growth turning positive when the CLI reaches 3 or more. An analysis of the separate effects of the $\mathbf{I} / \mathbf{E}$ and $\mathbf{P}$ components shows that although both show positive relationships similar to the one with the CLI, there is a slightly stronger association of growth with the cumulative $\mathbf{I} / \mathbf{E}$ component alone than with the full CLI, and a weaker relationship with $\mathbf{P}$. 
Figure 2: Growth and Liberalization

The CLI in this equation as well as the one for inflation results in a higher R2 than similar equations where the independent variable is the annual LI for 1994 or the average annual LIs for 1993/94. This suggests that the duration, as well as the intensity, of reforms is important. Furthermore, substituting a CLI with graduated annual weights (giving greater weight to more recent years) for a CLI with equal annual weights results in a higher or equally high R2, suggesting that use of a limited six-year period is reasonable even though some countries (Yugoslavia, Hungary, Poland) had a prior history of significant reform during the 1980s.

A multiple regression for average growth over the full six year period, 1989-94, for all $26 \mathrm{CEE} / \mathrm{FSU}$ countries, provides some additional insight into the relationship between growth and liberalization. Per capita income in 1989 (PCY) is introduced to allow for the negative effects of more pervasive central planning and overindustrialization in the more highly developed CEE and FSU countries. As discussed earlier, output declines resulted from disruption in these centralized coordinating mechanisms.

$$
\text { AVGR }=-9.1+2.6 \mathrm{CLI}-.54 \mathrm{PCY}-6.5 \mathrm{WAR} \quad \text { Adj R2 }=.65
$$

The WAR dummy shows that war is associated with average declines of an extra 6.5 percentage points. A linear relationship to the CLI fits better than a quadratic one, suggesting that the positive impact on growth of economic liberalization is equally strong in the upper ranges of growth, rather than declining as suggested by the quadratic relationship. To summarize:

- Cumulative liberalization has a positive effect on output changes in CEE/FSU, within the overall context of a "transitional recession."

The distinctive response patterns of China and Vietnam relative to those of CEE/FSU appear to be explained by several factors. Perhaps most important is these countries' large rural economy where decentralized incentives led to a big output boost from new firms and family farms. In China, an economy less centrally planned than the FSU and low integration into the CMEA trade bloc, hence insulation from the shock of dissolution, were additional factors. ${ }^{20}$

\section{Inflation and liberalization}

Recent inflation shows systematic variation by reform group in Table 2, and further evidence of a strong relationship between inflation and cumulative liberalization over the full sixyear period is provided in Table 3 . This evidence shows that advanced reformers were relatively

20 See, for example, Sachs and Woo 1994 and Thuyet 1995. 
successful in containing the inflationary bursts that followed price liberalization, while intermediate performers have endured longer and more severe bouts of inflation. The continuing high levels of inflation in the slow reformers suggest that they have delayed, rather than avoided, adjustment.

\section{Table 3: Inflation Experience by Reform Group, 1989-94}

Inflation seems to decline more slowly in the FSU in response to stabilization measures. In the non-Baltic FSU, for example, a widening of industrial price-cost margins is believed to reflect monopolistic pricing during the initial inflationary surge (Balcerowitz and Gelb 1994). However, the record of the Baltics, as well as of more recent stabilizers such as the Kyrgyz Republic and Moldova, suggests that, with determined policies, inflation can be brought down to moderate levels as quickly as in CEE.

Regression analysis indicates a strong negative association between inflation and economic liberalization. The R2 of a simple log linear relationship for the $20 \mathrm{CEE} / \mathrm{FSU}$ countries not affected by war is over 80 percent, suggesting a close relationship between economic liberalization and 1993/94 average inflation (Figure 3). An analysis of the separate effects of the $\mathbf{I} / \mathbf{E}$ and $\mathbf{P}$ components shows that both have a strong relationship with inflation, although neither has as strong a relationship as does the CLI; the I/E component again shows a stronger association than the $\mathbf{P}$ component.

\section{Figure 3: Inflation and Liberalization}

A multiple regression for all $26 \mathrm{CEE} / \mathrm{FSU}$ countries shows that cumulative economic liberalization, output decline, repressed inflation, and war are all associated with average inflation. Output decline is included to capture the fact that a fall in the transactions demand for money will-other things being equal-result in higher inflation. The relationship is estimated over the most recent four years only to avoid the effects of inherited inflation:

$$
\begin{aligned}
& \text { AVLIN1 } / 4=3.4-.88 \mathrm{LCLI}+.64 \mathrm{LDROP}+.036 \mathrm{RINFL}+1.2 \mathrm{WAR} \\
& \begin{array}{l}
(2.4)(2.3) \\
(1.5)
\end{array}(2.1) \quad(2.8)
\end{aligned}
$$

$$
\text { Adj. } R 2=.76
$$

where LDROP represents the $\log$ of the maximum drop in the annual index of real GDP for each country $(1989=100)$; RINFL represents repressed inflation defined as the increase in deflated wages less the change in real GDP during 1987-89; and WAR is a dummy variable for countries affected by war. In general:

- CEE and FSU countries that failed to liberalize experienced far higher inflation over the 1991-94 period. 
By contrast, China and Vietnam experienced relatively stable prices over this period, even though the extent of liberalization was less than in the CEE and FSU advanced reformers. The policy of gradual liberalization over a number of years-since 1978 for China and since the mid-1980s for Vietnam-has created a less disruptive environment, as has the lack of serious regional conflict. Moreover, the absence of initial monetary overhang and subsequent output drops allowed prices to be liberalized without provoking a sudden major burst of inflation and the associated flight from domestic currency.

\section{Growth and stabilization}

In market economies, it is usually assumed that stabilization carries a cost in terms of growth. But it is clear from cross-country data in Table 2 that output recovery in transition economies is associated with declining inflation. A two-way causality between growth and stabilization is likely to exist, as recovery will have a favorable impact on budget deficits, reducing inflationary pressures. Figure 4 plots changes in output against experience with stabilization, where the latter is defined as the year of highest inflation and all subsequent years. Inflation is measured as the annual average and is introduced with a one year lag. The statistical relationship suggests that a return to positive growth requires inflation to drop below 100 percent a year.

\section{Figure 4: Growth and Stabilization}

The numbers on the graph refer to a country's CLI at the time of the observation. They confirm a strong relationship between liberalization and stabilization which is consistent with the above discussion of liberalization and inflation. The most important outliers, notably Albania and Turkmenistan, benefit from growth led by primary sectors, agriculture and natural gas respectively. An important policy implication is:

- Output recovery in CEE and FSU countries requires stabilization of prices to moderate levels.

A related issue is the perceived output cost of stabilization. Because transition economies initiated the reform process under negative growth conditions and all registered large declines of output, some policy-makers argued during transition that stabilization would involve substantial output costs and adjustment should be gradual. ${ }^{21}$ On the other hand, some analysts, noting that output falls coincided with tight stabilization programs in CEE, argued that such programs exacerbated output contraction. ${ }^{22}$

\footnotetext{
21 Most FSU leaders subscribed to this point of view. See Fedorov (1995) in the case of Russia and World Bank (1993) for Uzbekistan.

22 See Portes (1993) who argued this point of view.
} 
There are two factors which have made these concerns unwarranted. First, declines in the early stages of transition were largely attributable to permanent relative price changes and structural demand shifts, which turned a substantial portion of previous production into negative value-added. This necessitated a change in output composition, which is shown below to occur at a rapid rate in high CLI countries. As we show in the paper, this was accompanied at the same time by stabilization and lower output drops in high CLI countries; lower because output drops in this group were moderated by the rapid growth of previously repressed sectors. Second, the fall in output was greater in the FSU countries where stabilization was not attempted until recently. Taken as a whole, these factors suggest that the output cost of stabilization has not been large. ${ }^{23}$ In fact, since stabilization preceded growth in CEE, it seems that the opportunity cost of not stabilizing would have been potential growth, which in turn suggests the cost of not stabilizing is actually higher than the cost of doing so.

Neither the CEE and FSU countries affected by war nor China and Vietnam are included in this analysis. Most of the former were still suffering from high inflation in 1994-although Croatia and the FYR Macedonia had recently introduced stabilization programs-and the latter were growing strongly throughout the $1989-94$ period in an environment of low to moderate inflation.

\section{THE TIME PROFILE OF GROWTH AND INFLATION}

Here, we investigate whether there are common patterns in the time profile of country experience which go beyond the broad relationships proposed above. We do this in two ways. The first way is to estimate "regime-switching" equations to provide stylized profiles of reformers and non-reformers. The second way is to trace the experience with growth and inflation of the four reform groups identified earlier. In both cases, we are looking at the interaction of growth and inflation over time. We exclude the East Asia experience as patterns differ there. ${ }^{24}$

Under the first approach, we estimate "regime-switching" equations across all $26 \mathrm{CEE}$ and FSU countries. However, to do this, we need to define the year in which the regime changes. This is easy for countries such as Poland that made a decisive change in a given year. It is harder for countries where reform has been more gradual or more partial. To avoid arbitrary specification of the switch points, we set the regime change on the basis of the CLI.

\footnotetext{
23 In his analysis of 28 high inflation episodes, Easterly (1995) also found that inflation stabilization was expansionary on average. Sargent (1992) in his analysis of hyperinflation in Austria, Germany, Hungary and Poland also argued that output costs of stabilization programs in those countries were small.

24 When China and Vietnam are included in the regression analysis, for example, the signs and values of the equation coefficients are similar, but the overall explanatory value is slightly less; their experience does not fit the profile of the other countries.
} 
First, the CLIs were rescaled so that Poland would have 5 years of reform by end-1994, implying that the new regime started in January 1990 (5 years earlier), as was the case. As all CLIs are normalized by the same factor (1.2), the implication is that countries' reform experience is being judged in "Poland-equivalent-reform" years.CLI. ${ }^{25}$

Once rescaled, the new CLI is rounded off to the nearest year. Working backward from end-1994, each country has at least one observation in the reform regime and one in the nonreform regime. For example, Poland has one observation (1989) in the non-reform regime and 5 observations (1990-94) in the reform regime. Turkmenistan, with the lowest CLI, has 5 observations (1989-1993) in the non-reform regime and one (1994) in the reform regime.

The equation specifying the time profiles of growth (GR) and inflation (INFL) relative to reform is as follows:

where:

$$
G R(I N F L)=a+\sum_{i=89}^{R-1} b_{i} D_{i}^{B}+\sum_{j=R}^{94} c_{j} D_{j}^{A}+d W A R
$$

$D_{i}^{B}$ are dummy variables for the successive years before reform begins for each country, starting in 1989;

$D_{j}^{A}$ are dummy variables for successive years after reform begins;

WAR is a dummy variable set equal to one for each year when war or associated blockades seriously affect a given country; and

$R$ is the year of reform.

Thus, dummy variables are used to define the variation in country experience in relation to the timing of reform and to capture the different economic experience of countries affected by war.

25 Two possible alternatives were considered: (i) to set the switch point according to the announcement of a comprehensive reform program (as in EBRD 1993), and (ii) to set the switch according to the year of maximum increase in the LI. These procedures are unsatisfactory because they fail to take into account the actual degree of reform. In any case, the general pattern of results is surprisingly robust to a variety of ways of deriving the switch point from the CLI index. 
Table 4 shows the estimated coefficients of these equations. ${ }^{26}$ When added to the intercept, they provide the growth and inflation time profiles of a regime of non-reform (the $b$ coefficients) versus a regime of reform (the $c$ coefficients). Caught in the deteriorating environment of a disintegrating economic system, non-reformers initially succeed in delaying the decline in output. Performance then contracts at an accelerating rate, so that after three years their position has deteriorated strongly compared to the reformers. Cumulative output declines are far higher than in the reform regime, indicating that the status quo is not a viable option for countries experiencing the disruptions in internal and external economic coordination discussed in Section II. Although theoretically it might be possible to follow a gradualist reform program, empirical evidence suggests that gradualism has not paid off.

\section{Table 4: Switching Regressions}

The growth regression shown in Figure 5 has reasonably good explanatory power, for an essentially cross-section relationship. The time profile shows that reforming countries experience a sharp contraction in the first year of reform but begin to recover after four years. The dummy variable coefficient for countries affected by war indicates a high and statistically significant additional cost of conflict. Each year of war reduces output by an additional 9 percentage points.

\section{Figure 5: Growth Profiles for Reform and Non-Reform}

As indicated in Section I, there are various hypotheses about the bias in underreporting of output. To assess sensitivity, we assume that official GDP not only understates real GDP in transition countries but that it understates the unofficial economy more in countries experiencing the largest declines because these countries have the weakest statistical systems. ${ }^{27}$ We have therefore undertaken a simulation exercise to test the robustness of the growth profiles discussed above. All countries are assumed to have a GDP adjustment coefficient of 1.15 with respect to their official economy in 1989, and this coefficient in subsequent years increases proportionally more in economies with the largest output drops. The resulting GDP adjustment coefficients for underground economies range from 0.2 for Hungary to 0.5 for Georgia. ${ }^{28}$ The results of the switching regression are quite similar for the adjusted data.

\footnotetext{
26 We have attempted to assess the stability of coefficients between the earlier and later reformers. Preliminary results do not usually reject the hypothesis of stable coefficients, but such tests are problematic with limited observations, especially because, given the period covered, early reformers do not have many pre-reform years as observations and late reformers have few post-reform years.

27 This adjustment is the least favorable to our hypothesis as it supports the view that the unrecorded economy is higher in countries that have liberalized less (and have the largest recorded output drops). On-going research by Daniel Kaufman of the World Bank provides support for the view that the informal economy is higher in countries that have liberalized politically but not economically; the adjustment here has the same feature.

28 The formula for calculating the adjustment coefficient for 1994 is: $1.2+(1.5-1.2) *$ [(country i's drop in GDP since 1989) - (the minimum drop in GDP in sample)]/[(maximum drop in GDP in sample) - (minimum drop in GDP in sample)]. Adjustment coefficients for intervening years are derived by interpolation.
} 
The implied inflation rates for reform and non-reform prototypes are shown in Figure 6. The stage of liberalization is a surprisingly strong predictor of inflation. As expected, liberalization is associated with a sharp price spike in the first year. In subsequent years, inflation is usually brought down, typically to about 20 percent after four years. Slow reformers initially manage to sustain inflation rates at moderate levels. After three years, however, their inflation rates soar far above the peak levels in the reforming countries as their economies contract sharply. As might be expected from the severity of their output losses, inflation is significantly higher in war countries than would otherwise be expected, given their liberalization profiles.

\section{Figure 6: Inflation Profiles for Reform and Non-Reform}

Under the second approach to exploring the time profile of transition, we analyze the experience of the $20 \mathrm{CEE}$ and FSU countries in the four reform groups identified earlier and use regression analysis to trace the average experience of each of these groups, as it starts reform, over the reform period. Using the normalized CLI, representing Poland-equivalent reform years, advanced reformers are assumed to start reforms in 1990, high intermediate reformers in 1991, low intermediate reformers in 1992, and slow reformers in 1993. The main finding is that each reform group follows a similar pattern. Figure 7 shows that advanced reformers effectively initiated reform in 1990 and growth turned positive after three Poland-reformequivalent years. Output declines for other groups accelerate as each begins reform, and these declines were increasingly prolonged and/or severe for the slower reformers. By 1994, only the advanced and high intermediate reformers had returned to positive growth, on average. Low intermediate and slow reformers continued to experience major output declines.

\section{Figure 7: Paths of Growth by Reform Group}

A clear pattern can also be seen for inflation. In all groups, initial price liberalization led to a jump in inflation in the year of reform (Figure 8). In advanced reformers, inflation rose quickly and then declined; elsewhere, it rose after some delay but remains high. Some regional variation in inflation experience is evident. The highest inflation has occurred in the non-Baltic FSU, where participation in the ruble zone has resulted in imported Russian inflation. But experience in Eastern Europe suggests that even had the other former Soviet republics rapidly introduced their own currencies, many would not have been able to maintain price stability given the slowness of their liberalization programs. Indeed, the introduction of new currencies in former Soviet states has frequently been marked by very high inflation.

\section{Figure 8: Inflation by Reform Group}




\section{UNDERLYING MACROECONOMIC AND SECTORAL PATTERNS}

\section{Patterns underlying growth}

Why do growth rates seem to rise after a period of liberalization and stabilization? There are several possible explanations: (i) an increased flow of external finance; (ii) a recovery in investment levels; (iii) increases in employment; and (iv) an accelerated process of economic restructuring. We examine them in turn. Structural change appears to be the main factor.

(i) External finance. The role of external resources in the transition process has been debated (IMF 1994, EBRD 1994, Sachs 1994, Dabrowski 1995). On the one hand, Dabrowski has argued that too much finance too early can weaken pressures for reform. On the other, external finance can encourage adjustment by providing investment resources and noninflationary financing of temporary fiscal deficits. The availability of foreign finance also depends on the reforms themselves, so that two-way causality is expected.

Table 5 shows the current account balance of payments as a percentage of GDP in 1989-94 and in 1994. On (unweighted) average, current deficits have been modest over the period in groups 1 and 4, larger in the intermediate groups 2 and 3, and in the war countries, especially those in the FSU. The picture in 1994 points to larger deficits among the least reformed countries.

\section{Table 5: Net External Financing and Fixed Investment}

Current accounts have varied a great deal between countries however, for a variety of reasons. For example, Turkmenistan's 1994 deficit reflects repayment of previous involuntary export credits to natural gas importers, while that of the Kyrgyz Republic shows its ability to attract external assistance as the most advanced reformer in Central Asia. Mongolia, Albania and Moldova have also benefitted from high external assistance. ${ }^{29}$ In general:

- Net external finance has little systematic relationship with the extent of reform or growth performance.

(ii) Investment. ${ }^{30}$ According to official data, fixed investment continues at moderate levels, and varies only slightly, relative to GDP, across the four reform groups (Table 5). Private investment and GDP are, of course, inadequately captured. Only Ukraine and Turkmenistan are reported as suffering a complete investment collapse.

\footnotetext{
29 Between 1991 and 1994, some Central Asian republics received large export credits from Turkey while Ukraine, Belarus, Armenia and several Central Asian republics received monetary transfers and "technical credits" from Russia to cushion terms of trade shocks from the liberalization of energy prices.

30 The focus here is on fixed investment, since estimates of total investment are particularly unreliable for transition economies; changes in stocks are estimated for some countries to be plus or minus 20 percent or more of GDP.
} 
Fixed investment was high in most of the countries prior to reform, ranging from 21 percent of GDP in Hungary to 44 percent in Mongolia (which received transfers from the USSR equivalent to 30 percent of GDP). Levels were higher in the Soviet Union than in Eastern Europe however, so that the decline between 1989 and 1994 was only 4 percent of GDP in group 1, compared with 14 percent and 12 percent in groups 2 and 3 respectively. While the more buoyant economies of group 1 may have sustained investment spending, the larger declines in the less advanced reformers mainly reflects their higher-and more wasteful-pre-reform levels. In general:

- Fixed investment rates differ only slightly among reform groups. Investment is at moderate levels for many transition countries, but far below previous highs.

(iii) Employment. It is very difficult to obtain a reliable time series of employment in transition countries; but initial levels of labor force participation in transition countries were very high. Statistics on unemployment do exist, however, and Table 6 shows the association between registered unemployment levels in 1994 and the CLI. Unemployment is a noisy transition indicator, and there is considerable cross-country variation in the incentives to report. Registered unemployment varies greatly from any pattern that might be expected from recorded declines in output-indeed, it tends to be higher in the countries where output has recovered the most.

\section{Table 6: Registered Unemployment through Transition}

This may reflect the success of these countries in downsizing or closing loss-making firms, and freeing up resources for new activities. It may also reflect a tendency for recorded levels to be higher in Eastern Europe than in FSU countries comparably advanced in the reform process. For example, a considerable proportion of the unemployed recorded in Hungary are believed to have been working, and Vodopivec (1994) finds evidence in Slovenia that the duration of registered unemployment is closely associated with the duration of benefits, with many people "finding work" in the last months of eligibility. In contrast, limited unemployment benefits in Armenia and the stigma associated with being unemployed result in low recorded unemployment even though energy shortages have heavily constrained industrial activity.

Unemployment estimates must be interpreted with caution, but the negative relationship with growth is striking, particularly since higher unemployment in market economies is typically associated with lower labor force participation because of the "discouraged worker" effect. In general:

- The negative association between registered unemployment and growth make it unlikely that large increases in employment underlie output recovery.

(iv) Structural change. Table 7a shows the shifts of output in current prices between broad production sectors, and Table $7 \mathrm{~b}$ shows the corresponding shifts in constant prices. The more advanced reformers have experienced an accelerated shift from industry, which was 
overbuilt, towards services, which were repressed. This shift reflects higher profitability in the growing sectors and leads to faster output recovery. On average, the share of current price services in GDP has increased by 15 percentage points in the advanced reformers, 10 percentage points in the high intermediate reformers, and 7 percentage points in the low intermediate reformers. ${ }^{31}$

\section{Table 7a: Sectoral Shifts at Current Prices}

\section{Table 7b: Sectoral Shifts at Constant Prices}

These structural shifts have occurred despite the fact that services fell, relative to GDP, in almost all FSU countries between 1990 and 1992, due to a precipitous decline in government (including military) services. Growth in services has been concentrated in private trade, finance and other business and consumer services. These activities represent a major locus for private wealth accumulation, which-in some countries-is now starting to be used to acquire industrial assets. ${ }^{32}$ Service growth is undoubtedly severely understated because of the underreporting of private activity, but its growth may also be exaggerated by the fact that many services were previously incorporated into industrial firms and not separately distinguished.

In the more advanced reformers, the fall in industrys share has been across-the-board, including military production, heavy industry and consumer manufactures uncompetitive with imports. A striking development has been the sharp deconcentration of industrial employment by firm size (see, for example, Kornai 1994 and Balcerowitz and Gelb 1994). This has resulted from a combination of new private entry, layoffs from the state sector, and the breakup of large state firms, sometimes in the course of spontaneous processes separating good and bad assets prior to privatization. ${ }^{33}$

According to official statistics, the shift away from industry has not taken place in the countries with low CLIs. Indeed, industry's measured share has actually risen for some low intermediate and slow reformers. Service sectors are certainly larger than estimated officially, as some services are included in the unofficial economy, but they are less well developed than in countries with high CLIs. Also, where reforms are slow, service sector growth may not signal private sector growth; government-owned monopolies have been known to absorb previously autonomous firms (tourism in Uzbekistan) and to have created higher regulatory barriers to entry.

\footnotetext{
31 Not much weight can be put on differences between current and constant price data for services; even for market economies, deflators for many services are problematic.

32 One example is the 1995 purchase of Russian energy companies by a consortium of Russian banks.

33 Such processes have been especially powerful in Hungary: see Brada, Singh and Torok 1994.
} 
The relative performance of agriculture varies considerably among countries. Pre-reform agriculture was inefficiently organized but benefitted from subsidies, including through credit, energy and other inputs. Performance during the transition reflects a variety of effects, including privatization in some countries, relative price changes (which have especially hit the livestock sectors) and a critical emerging shortage of liquidity at farm level. Widespread drought in Eastern Europe in the early 1990s also complicates the picture. High intermediate reformers with a strong agricultural response include Romania, Albania and Mongolia; all are leaders in agricultural privatization. Among the slow reformers, Ukraine has experienced a substantial shift from industry to agriculture, reflecting a strong comparative advantage in farming. Recorded output patterns for the "war" economies are distinctive. Faced with overestimated, but still very large, declines in aggregate activity, populations have retreated towards subsistence farming. In general:

\section{- Dramatic changes in the sectoral composition of GDP underlie the recovery in real output.}

Statistical measures of the transition between "socialist" (generally public) and "market" (generally private) sectors of the economy are not readily available for all countries, but rough measures confirm a picture of higher private sector shares as liberalization progresses.

\section{Patterns underlying inflation}

Why has inflation come down in countries following a period of liberalization but remained high for others? There are several possible explanations: (i) exchange rate movements; (ii) conventional budget deficits; (iii) quasi-fiscal deficits; and (iv) monetary developments. These are examined in turn. The main spur to inflation appears to have been from quasi-fiscal deficits and the associated monetary expansion.

(i) Exchange rate movements. Figure 9 shows the ratio of the nominal exchange rate to an estimated purchasing power parity (PPP) rate as an indicator of the real exchange rate. ${ }^{34}$ In both floating-rate and pegged-rate countries, large real exchange rate depreciations occurred during the early stages of reform in conjunction with price liberalization and elimination of the money overhang. These huge real devaluations sustained external balance but surely exacerbated inflationary pressures at the time. Subsequently, however, exchange rates strengthened towards a market rate of twice the PPP rate, a ratio consistent with comparable ratios for countries at comparable levels of PPP income (Balcerowitz and Gelb 1994). In general:

- Large depreciations of the real exchange rate occurred during the early stages of liberalization, but the ratio of real rates to PPP rates was subsequently fairly steady.

\section{Figure 9: Ratio of Market Exchange Rates to PPP Rates}

\footnotetext{
34 As pointed out in Balcerowicz and Gelb 1994, exchange rates that prevailed under central planning cannot be used to impute equilibrium values.
} 
(ii) Conventional budget deficits. As Table 8 indicates, revenue shares in GDP averaged 50 percent for the advanced reformers in 1994-some 4 percent lower than in $1989 .{ }^{35}$ At 33 percent of GDP on average, revenues in high intermediate reformers had stabilized in 1994 but at far lower levels than before. At 24 percent of GDP, revenue shares were lowest in the low intermediate reformers. In Mongolia and some former Soviet republics, revenue declines reflect the elimination of previous large budgetary transfers from the center.

In the slow reformers, reported revenue shares have fallen only in Turkmenistan where trading partners failed to pay for gas exports. However, revenue performance is partly spurious-reflecting payments to the budget taken out of credit subsidies from the Central Bank (see below). The surprisingly strong performance of "war" countries was largely due to the inclusion of foreign grants: in Georgia, revenues net of grants collapsed to 3 percent of GDP in 1993.

\section{Table 8: Revenue, Expenditure, and Fiscal Balance}

Except in the advanced reformers, expenditures typically fell less than revenues and in some cases they increased substantially relative to GDP. The largest increases in expenditure shares were in the "war" countries, although slow reformers also showed some increases on average. In advanced reformers, cuts in subsidies ranged from 7 to 10 percent of GDP, although these were offset by rising social expenditures. ${ }^{36}$

Fiscal deficits increased on average for all CEE and FSU groups except advanced reformers between 1989 and 1994. Deficits averaged 2 percent of GDP in advanced reformers and 7 percent of GDP in intermediate reformers. They were surprisingly modest in slow reformers still experiencing very high inflation. In general:

- Fiscal revenues and expenditures have been maintained in advanced and slow reformers but have fallen dramatically in intermediate reformers. Open fiscal deficits have been moderate in most countries.

(iii) Quasi-fiscal deficits. Quasi-fiscal expenditures may include extra-budgetary financing for debt write-offs, implicit subsidies in connection with foreign exchange guarantee schemes, and implicit subsidies resulting from the provision of credit to banks and firms at highly negative real interest rates. This last category, which reflects attempts to maintain production and employment in industry and agriculture, is shown in Table 9 for a range of

35 See EBRD (1994) and IMF (1994). The common pattern was for revenues to decline during the first year of reforms but to rebound starting in the second year.

36 This substitution was predicted by Bruno (1993) and pointed out by EBRD (1994) and Coricelli (1994). In Hungary and Poland, increases in social security expenditures have been particularly large. In 1993, social spending amounted to 18 percent and 20 percent of GDP respectively. Hungary and Poland have also experienced a steady rise in interest payments on debt, to around 4 to 5 percent of GDP. As a result, total expenditures reached close to 60 percent of GDP in Hungary and 50 percent in Poland, higher than the European Union average. 
countries. The subsidies shown are calculated as the difference between the central bank discount rate and the inflation rate, applied to gross monthly (or quarterly) central bank credit outstanding to the non-government sector. ${ }^{37}$ Estimates of the other quasi-fiscal expenditures are more difficult to obtain on a comparable basis. ${ }^{38}$

\section{Table 9: Fiscal Deficits and Quasi-Fiscal Expenditures for Selected Countries, 1992-94}

In countries where reforms lag and structural change has been resisted, the consolidated deficits, also shown in Table 9, are much larger than open fiscal deficits. ${ }^{39}$ Central bank subsidies in the slow reforming countries have been on the order of three times the fiscal deficit, and far exceed any plausible estimate of tax revenue recouped from subsidized firms. Only in more advanced reformers, where stabilization is more or less achieved and rapid structural change is in process, have these losses been eliminated. Declines in the consolidated deficits in 1994 for several slow reformers are encouraging in this respect.

\section{- Quasi-fiscal losses have been the major inflationary force in the slower reformers.}

(iv) Monetary developments. Table 10 shows real money growth, real money balances, and real interest rates across countries. ${ }^{40}$ Nominal growth of broad money during 1992-94 has been lowest in advanced reformers and highest in slow reformers, and in countries affected by war. ${ }^{41}$ The relatively low money growth of the advanced reformers was accompanied by policies allowing real interest rates to rise to either positive or slightly negative levels. Only in these countries have real money balances actually increased on average.

\section{Table 10: Money, Interest Rates and Real Balances}

Broad money grew rapidly in intermediate and slow reformers while real interest rates were substantially negative. Real money balances fell sharply in 1992. Thereafter, they

\footnotetext{
37 Quasi-fiscal losses are computed on average balances by month or quarter, and are divided by estimated monthly (or quarterly) GDP to obtain a percentage subsidy flow. These are then averaged, to obtain the annual average.

38 Extra-budgetary debt write-offs have been estimated at an additional 3.4 percent of GDP in 1992 and 3.8 percent of GDP in 1993 for Bulgaria, and such write-offs are known to exist in other countries, such as Hungary and Kazakhstan. The importance of such write-offs would be expected to mount after real interest rates are increased to positive levels.

39 For comparison, central bank subsidies to state enterprises in China have been substantial over the last 5 years, but this has not so far caused excessive inflation because of rapid growth in the demand for money. See "China: State Finances" in Oxford Analytica, March 9, 1995. See also McKinnon (1993), Cardoso and Yusuf (1994).

40 For a discussion of conceptual issues and detailed reviews of monetary policy issues during transition see (Edwards 1992), Bruno (1993), Bredenkamp (1993), Sachs (1995), Sahay and Vegh (1995), Citrin, Anderson, and Zettelmeyer (1995).

41 For transition economies, Citrin, Anderson, and Zettelmeyer (1995) support the view that nominal money growth is the best indicator of policy stance-better than real money growth or real interest rates. See de Grauwe (1995) for a more general discussion of assessing the stance of monetary policy.
} 
stabilized in the high intermediate reformers but continued to decline in the slower reformers. The real discount rate on central bank credit seems to have risen in 1994, although there is substantial variation across the countries.

These patterns reflect the strong causal links between structural reforms and monetary developments. Restrictive monetary policies in advanced reformers not only allowed stabilization; they facilitated currency convertibility and liberalization. Liberalization, in turn, was needed to render effective the hard budget constraints that allow restrictive macro-policies to be sustained. Liberalization and stabilization, together, have then impelled the reallocation of real resources. In intermediate and slow reformers, continued large subsidies to state-owned agriculture and industry have been financed by central bank resources, but loose monetary policies did not prevent continued drops in output through the end of 1994. Output recovery appears to be related to the improved allocation of available resources rather than to more relaxed monetary policy. In general:

- Monetary and interest rate patterns are consistent with the progression of reforms.

\section{LIBERALIZATION AND POLITICAL FREEDOM}

The above discussion highlights the central importance of liberalization in the transition process, and we close by asking the question: "What determines the pace of liberalization?" We explore the hypothesis that economic liberalization is associated with political change. ${ }^{42}$

Country rankings of the Cumulative Liberalization Index are shown in Table 11 along with measures of political freedom provided in the Comparative Survey of Freedom for 1994 (Karatnycky 1995). This survey has been published annually by Freedom House since 1973 and is defined by traditional political rights and civil liberties of Western democracies. The two components of the index are highly correlated and in previous research gave very similar results when used separately (Helliwell 1994). Country rankings, based primarily on responses to a checklist of indicators, reflect the judgment of a project team that consults a vast array of published materials as well as regional experts and human rights specialists.

The Survey is not a score card for governments, but rather an assessment of the effect on personal freedoms caused by both government and non-government (e.g., military or religious groups) factors. There is some evidence that the Survey findings are robust (Inkeles 1990). Following a conference in 1988 on measuring democracy, Inkeles concludes that the underlying measures of political freedom are common to all rating systems, even if specific indicators vary, and that there is high agreement in the results of alternative classifications.

\section{Table 11: Political Freedom and Degree of Liberalization}

\footnotetext{
42 See de Melo, Denizer, Gelb and Tenev (1995, forthcoming) for further analysis of the determinants of economic liberalization.
} 
In Table 11, the Spearman rank correlation coefficient for all 26 CEE and FSU countries is $0.8{ }^{43}$ Excluding the war countries, it is 0.91 -indicating a very close correspondence indeed. A non-linear relationship fitted to the data of all $26 \mathrm{CEE} / \mathrm{FSU}$ countries, excluding China and Vietnam, is shown in Figure 10. It indicates accelerated economic liberalization at higher levels of political freedom, and in general supports the following proposition:

\section{- Economic liberalization is typically associated with a similar degree of political change.}

Figure 10:

Political Freedom and Degree of Economic Liberalization

One explanation for this high correlation between political freedom and liberalization could be that both variables are strongly associated with an unidentified latent variable such as income. But Pearson and Spearman correlations between each of these variables and (purchasing power parity) per capita GDP in 1989 are lower ( 0.39 for both in the case of liberalization and 0.47 and 0.48 respectively in the case of political freedom) than those between the two variables themselves ( 0.75 and 0.79 respectively). The lower correlations between political freedom and income levels are consistent with the failure of global cross-country research to establish a systematic relationship between political freedom and economic growth (Helliwell 1994). They also suggest a need to look more closely at the relationship between political change and reform at the individual country level to understand the particular circumstances of the transition economies.

In CEE/FSU countries where former communist party leaders have held power continuously (Uzbekistan, Turkmenistan, Kazakhstan, and Ukraine), reforms have been slow and driven largely by macroeconomic pressures arising from the breakup of the USSR and attempts to maintain the status quo. In countries where there was a clear break with the previous communist regime (Poland, Hungary, Czech Republic, Albania, Lithuania, Estonia, and Latvia), liberalization has been most radical, as reflected in a rapid change in the annual LI from near zero to close to one during a phase of "extraordinary politics" (Balcerowicz 1993). So far, there has been little reversal of such movements to liberalize, even where "socialist" political parties have regained control (as in Lithuania, Poland, Hungary and Estonia) ${ }^{44}$

Where power has been shared among a broad spectrum of political interests (Russia, Bulgaria), or where local governments have opposed reforms initiated from the top (Russia), reforms have typically been halting and sometimes inconsistent, placing such countries in the intermediate category. In Bulgaria, for example, initial liberalization of internal and external

\footnotetext{
43 The Pearson correlation coefficient for political freedom and the CLI for CEE/FSU countries is 0.75 and statistically very significant. The correlation for the CLI and level of development, as measured by purchasing power parity per capita income in 1989 , is lower at 0.4 , but also statistically significant.

44 The lack of reversal is consistent with the view of Aslund 1994 that democratization checks the power of the old elite.
} 
markets, impelled by a particularly difficult macroeconomic situation, was not matched by corresponding progress on private sector entry. Moldova offers a similar experience. In contrast, unlike most non-Baltic FSU countries, Russia and the Kyrgyz Republic reforms in support of private sector entry have moved almost as fast as other reforms. Mongolia has also moved quickly on private sector entry, with the first comprehensive privatization program among intermediate reformers, even though its initial reforms of internal and external markets were halting.

The example of China and Vietnam appear to contradict the link between political and economic reform. China and Vietnam have liberalized economically while retaining strict controls on political rights and civil liberties, and the inclusion of China and Vietnam results in a drop in the rank correlation coefficient to .62. However, continuity in leadership at the center masks a substantial decentralization of political power to provincial and local governments. China experts would probably agree that this political decentralization has played a central role in economic liberalization since the start of agricultural reforms in 1978. In Vietnam, the 1989 "renovation" reforms were followed by implicit decentralization of economic decision-making through emphasis on initiative at the local level. In both cases, the East Asia model of gradual, decentralized, economic transition appears to have a political counterpart, even if it is not political freedom per se.

Although the above discussion focuses on the effect of political freedom on economic reform, the direction of causality is actually two-way. Economic liberalization has strong political implications; it is an essential step in breaking the power of established structures, especially line ministries which previously controlled industry and trade. This is true even where liberalization does not lead to replacement of the political and managerial elite. ${ }^{45}$

\section{CONCLUSIONS AND IMPLICATIONS FOR POLICY DEBATES}

\section{Conclusions}

Countries in CEE and the FSU differ in many respects, and their transitional experience also varies widely. Nevertheless, the above analysis suggests strong common patterns for countries at similar stages of reform. The common legacy and the associated changes resulting from initial disruptions in the socialist economic coordinating mechanisms and subsequent liberalization measures go a long way toward explaining the transition experience.

\footnotetext{
45 With the exception of East Germany (where loyalty and competency tests were imposed), and Czechoslovakia (where a process of lustration was applied), leading communists and managers have typically been able to take advantage of political connections and technical expertise to redefine their role towards commerce and business management. See, for example, RonaTas 1994.
} 
Reform can be usefully though of as encompassing the duration as well as the intensity of economic liberalization, as defined by the liberalization of internal and external markets and facilitation of private sector entry. Analysis based on countries' cumulative liberalization provides a useful insight into country experience with growth, including the "transitional recession." Liberalization has been an important element of stabilization policy, even though its initial impact entails a spurt in prices, and even though liberalization is by no means a sufficient condition for regaining price stability.

The necessity, if not the inevitability, of liberalization derives from the weakening of governments that initiated a process of political glasnost as well as economic opening up. This precluded the application of direct controls that would have been needed to stabilize unreformed systems, where enterprises were not separated from government. The close relationship between economic liberalization and political freedom helps to explain why some countries moved more quickly on reforms and others did not.

An examination of the macroeconomic and sectoral patterns underlying this aggregate experience confirms the usefulness of classifying countries by stage of reform and suggests that many developments are bi-directional in nature. In advanced reformers, liberalization has permitted the reallocation of capital and labor from industry towards services and an associated return to positive growth from the expansion of previously repressed sectors. While the severe macroeconomic imbalances that built up in the last years of the Soviet Union are a costly legacy, the main problem in stabilization is continuing monetization of the fiscal and quasi-fiscal deficits, associated with attempts to maintain employment under the old system. Recent experience suggests that stabilization policy can be surprisingly powerful in FSU countries (Kyrgyz Republic, Moldova), but these countries will remain fragile until structural reforms take hold and resources for restructuring become available.

\section{Policy implications}

The above findings have several implications for recent policy debates:

Stabilization as a priority. These patterns shed light on a number of questions raised by other studies. Portes 1994 and others have argued that policies have overemphasized stabilization relative to structural reform. Although it is hard to respond to this view at a general level when the circumstances-say between Ukraine and the Czech Republic-differ substantially at the country level, it seems to us that such arguments miss the strong complementarity between macro and micro policy and the high apparent costs of sustained inflation in the slow-reforming countries.

The empirical analysis in this paper supports Ickes and Ryterman 1994 and Balcerowicz and Gelb 1994, who maintain that strong interactions between liberalization and stabilization are expected. It also supports the conclusions of Easterly and Bruno 1994, who have found evidence in other countries that neither the effective functioning of markets nor renewed investment is 
possible with severe macroeconomic price instability; thus, stabilization becomes a priority for the resumption of growth. Further, the analysis in this paper suggests output costs of stabilization has not been large. At the same time, it should be recognized that stabilization is rendered more difficult by severe output contractions during the early stages of liberalization; such contractions reduce potential tax revenues and raise claims on fiscal resources to cushion the effects. Stabilization is also rendered difficult by the absence of external financing and by the large depreciations in the exchange rate that accompany the early stages of liberalization.

Big bang versus gradualist approach. A continuing debate has been whether or not countries should follow a "big bang" or gradualist approach to reform. Two points can be made. First, the close relationship between economic liberalization and political freedom suggests that it may be unrealistic to expect a given regime to perceive, or in fact to have, a very wide range of options. Second, the time profiles estimated here suggest that to the extent that regimes do perceive or have options, rapid reform is preferable to slow reform, given the breakdown in the central planning apparatus. The status quo was not a viable option for CEE and FSU countries. Recorded inflation and output losses in countries that have managed to postpone adjustment are now far larger than in the more advanced reformers, even though transfers from Russia cushioned the terms of trade shocks for several other non-Baltic FSU countries into 1993.

Fiscal constraint on reform. Many analysts have emphasized the need for tight and active fiscal policies, to support stabilization and enterprise restructuring; they have also underlined the importance of quickly reforming the tax system. ${ }^{46}$ At the same time, fiscal deficits are expected to increase. The "transitional recession" and lags associated with the development of a new tax system are expected to result in a fall in revenues in the short run. And social expenditures are expected to increase as they are transferred from enterprises to the budget.

Some observers have in fact argued or implied that there is a "fiscal constraint" to rapid reform (Chadha and Coricelli 1994 and Aghion and Blanchard 1994). These studies note that there are fiscal costs, associated with closing or restructuring state enterprises, that need to be offset by revenues generated from new private businesses. Otherwise, the budget balance deteriorates as reforms are implemented; revenues from state enterprises decline while unemployment benefits increase. These studies further note that tax rates on the private sector need to be low in order not to discourage growth; so, meeting a target budget deficit may require measures to sustain state enterprises, the traditional tax base.

The cross-country comparisons carried out here suggest a different conclusion. As noted above, fiscal revenues and expenditures have tended to remain high, relative to GDP, in advanced reformers, and fiscal deficits have been noticeably smaller than in the slower reformers. Even if there are reasons-cultural, institutional, or structural-why the fiscal

\footnotetext{
46 See Fischer and Gelb 1991; Bruno 1993; Kopits 1991, 1993; Tanzi 1991, 1993; Balcerowicz and Gelb 1994; and Sachs 1994.
} 
position is stronger in advanced reformers, there is no convincing evidence that a slower pace of reform has strengthened the fiscal position of intermediate reformers. ${ }^{47}$ As suggested earlier, the lack of adjustment by state enterprises in the face of structural shifts in demand may result in negative value added for many of these enterprises, and therefore no taxable profits. The failure of slow reformers to maintain fiscal balance is highlighted by the fact that their consolidated fiscal plus quasi-fiscal deficits are even worse than those of intermediate reformers.

Choice of nominal anchors in stabilization programs. Substantial debate surrounds the choice of nominal anchors in stabilization programs (Sachs 1994, Sahay and Vegh 1995, and Citrin et al. 1995) The main choice has been between a money anchor and an exchange rate anchor, both often used in combination with restrictions on public sector wages; and the debate has been primarily over whether greater reliance should have been placed on the exchange rate anchor. The uncertainty of changes in money demand, the adequacy of foreign reserves and the role of the chosen anchor in signaling and establishing credibility are seen as choice factors. At the same time, it should be recognized that both money and exchange rate anchors have proven to be effective in a variety of stabilization programs in transition countries. This is consistent with the evidence here suggesting that the most critical factor for the success of stabilization in transition countries is likely to be the extent of economic liberalization irrespective of nominal anchor choice. As discussed widely in the literature, what is critical for the success of stabilization programs is their credibility and in the context of transition credibility does not come without extensive liberalization.

Unemployment as an indicator of reform. The strong association of unemployment with the CLI noted here supports Phelps et al 1994, who find rising unemployment to be a good indicator of transition. The higher levels of unemployment recorded in CEE, as compared to FSU, countries is also consistent with the differences, pointed out by other researchers, in incentives to register for unemployment and the extent to which firms respond through formal layoffs, to decreases in activity. The Kyrgyz Republic, one of the leading reformers in the FSU, also seems to be exhibiting similar employment patterns. Windell, Anker, and Sziracki (1995) show that enterprise employment fell by a third between 1991-94 which is consistent with rising unemployment data reported by the World Bank (1995).

\footnotetext{
47 It is certainly possible, for example, that the institutional infrastructure (tax code, tax administration, expenditure control) and general conditions of societal order and compliance are stronger in advanced reformers.
} 


\section{References}

Aghion, Philippe and Olivier Blanchard (1994). "On The Speed of Adjustment In Central Europe," in S. Fischer and J. Rotemberg (eds.) NBER Macroeconomics Annual, The MIT Press, Vol. 9, pp. 284-320.

Alesina, Alberto (1994). "Political Models of Macroeconomic Policy and Fiscal Reforms," in Voting For Reforms, S. Haggard and S. Webb (eds.), World Bank, Oxford University Press, pp. 37-60.

Aslund, Anders (1994). "Lessons of the First Four Years of Systemic Change in Eastern Europe," in Journal of Comparative Economics, Vol. 19, No. 1, pp. 22-39, August.

Balcerowicz, Leszek (1993). "Common Fallacies in the Debate on the Economic Transition in Central and Eastern Europe," EBRD Discussion Paper No. 11, October.

and Alan Gelb (1994). "Macropolicies in Transition to a Market Economy: A Three-Year Perspective," prepared for the World Bank Annual Conference on Development Economics, April 28-29, Washington, D.C.

Banerjee, Biswait, Vincent Koen, Thomas Krueger, Marl S. Lutz, Michael Marrese, and Tapio Saavalainen (1995). Road Maps of Transition, The Baltics, the Czech Republic. Hungary and Russia, IMF Occasional Paper No. 127, September 1995.

Bennett, Adam, G.G. (1994). "Currency Boards: Issues and Experiences," IMF Paper on Policy Analysis and Assessment 94/18.

Berg, Andrew (1993). "Recession and Structural Adjustment in Poland," paper presented at IMF Seminar entitled "Recession and Reform in Poland," January.

(1994). "Does Macroeconomic Reform Cause Structural Adjustment? Lessons From Poland," Journal of Comparative Economics, Vol. 18, No. 3, pp. 376-410, June.

and Jeffrey Sachs (1992). "Structural Adjustment And International Trade In Eastern Europe: The Case of Poland," Economic Policy: A European Forum, No. 14, pp. 117-173, April.

Blanchard, Olivier Jean, Kenneth A. Froot, and Jeffrey D. Sachs. The Transition in Eastern Europe: Volume II - Restructuring, The University of Chicago Press, Chicago.

Blejer, Mario I. and Adrienne Cheasty (eds.) (1993). How to Measure the Fiscal Deficit, International Monetary Fund, Washington, D.C. 
Brada, Joseph, I.J. Singh, and Adam Torok (1994). Firms Afloat and Firms Adrift: Hungarian Industry and the Economic Transition, M.E. Sharpe, London and New York.

Bredenkamp, Hugh. (1993). "Conducting Monetary and Credit Policy in Countries of the Former Soviet Union: Some Issues and Options," IMF Working Paper 93/23.

Bruno, Michael (1993a). Crisis, Stabilization and Economic Reform: Therapy by Consensus, Oxford University Press, Oxford.

Bruno, Michael (1993b). "Stabilization and the Macroeconomics of Transition: How Different is Eastern Europe?," in Economics of Transition, Vol. 1, No. 1, EBRD, pp. 5-19.

Burda, Michael C. (1994). Structural Change and Unemployment in Central and Eastern Europe: Some Key Issues, Discussion Paper Series No. 977, Centre for Economic Policy Research, London, June.

Calvo, Guillermo, Ratna Sahay and Carlos Vegh (1995). "Capital Flows in Central and Eastern Europe: Evidence and Policy Options," Draft IMF Working Paper.

and Manmohan S. Kumar (1994). "Money Demand, Bank Credit, and Economic Performance in Former Socialist Economies," Staff Papers, International Monetary Fund, Vol. 41, No. 2, pp. 314-349, June.

.and Carlos Vegh (1992). "Inflation Stabilization and Nominal Anchors," IMF Papers on Policy Analysis and Assessment 92/4.

Chadka, Bankim, Fabrizio Coricelli, and Kornelia Krajnyak (1993). "Economic Restructuring, Unemployment, and Growth in a Transition Economy," Staff Papers, International Monetary Fund, Vol. 40, No. 4, pp. 744-781, December.

and Fabrizio Coricelli (1994). Fiscal Constraints and the Speed of Transition, Discussion Paper Series No. 993, Centre for Economic Policy Research, London, July.

Chu, Ke-young and Gerd Schwartz (1994). "Output Decline and Government Expenditures in European Transition Economies," IMF Working Paper No. WP/94/68, International Monetary Fund, Washington, D.C., June.

Citrin, Daniel, J. Anderson, J. Zettelmeyer (1995). "The IMF's Approach to Stabilization in the Baltics, Russia and the Other FSU Countries, "Economic Policy in Transition Economies (MOCT), Kluwer Academic Publishers, Vol. 5, No. 2. 
Conway, Patrick (1995). Currency Proliferation: The Economic Legacy of the Soviet Union, Forthcoming, Princeton Studies in International Finance.

Coricelli, Fabrizio (1994). "Fiscal Issues in Transition Economies," Department of Economics, University of Sienna, Italy, September.

Dabrowski, Marek (1995). "Different Strategies of Transition to a Market Economy: How Do They Work in Practice?," mimeo, Transition Economies Division, Policy Research Department, World Bank.

de Grauwe, Paul (1995). "Monetary Policies in the EMS," in C. Bordes, E. Girardin, J. Melitz (eds.) European Currency Crises and After, Manchester University Press, New York.

de Melo, Martha, Cevdet Denizer, Alan Gelb, and Stoyan Tenev (1995). "Explaining Transition: The Role of Initial Conditions in Reforming Socialist Countries," Policy Research Department, World Bank, Washington, D.C.

Easterly, William (1995). "When is stabilization expansionary?," Working Paper, Policy Research Department, World Bank, Washington, D.C.

Easterly, William and Michael Bruno (1994). "Inflation Crises and Long-run Growth," mimeo, Policy Research Department, World Bank.

Easterly, William, Martha de Melo, and Gur Ofer (1994). "Services as a Major Source of Growth in Russia and Other Former Soviet States," Working Paper Series No. 1292, Policy Research Department, World Bank. Mario Blejer (ed.), Macroeconomic and Structural Aspects of Russian Economic Reform, International Center for Growth.

Edwards, Sebastian (1992). "Stabilization and Liberalization Policies for Economies in Transition: Latin American Lessons for Eastern Europe," in C. Clauge and Rausser (eds.) The Emergence of Market Economies in Eastern Europe, Basil Blackwell Publishers.

European Bank for Reconstruction and Development (1994). Transition Report, EBRD, London.

(1995). Transition Report Update, EBRD, London. April.

Fan, Qimiao and Mark Shaffer (1994). "Government Financial Transfers and Enterprise Adjustment in Russia, with Comparison to Central and Eastern Europe," World Bank Discussion Paper, Europe and Central Asia Region, Washington, D.C., June. 
Fedorov, Boris (1995). "Macroeconomic Policy and Stabilization in Russia," in Aslund, Anders (ed.) Russian Economic Reform at Risk, New York: Pinter.

Fischer, Stanley (1986). "Exchange Rate versus Money Targets in Disinflation" in Indexing. Inflation and Economic Policy, MIT Press.

and Alan Gelb (1991). "The Process of Economic Transformation," Journal of Economic Perspectives, 5(1).

Gelb, Alan, Gary Jefferson, and Inderjit Singh (1993). "Can Communist Economies Transform Incrementally? The Experience of China," in O. Blanchard and S. Fischer (eds.) NBER Macroeconomics Annual, The MIT Press, Vol. 8, pp. 87-133.

Hanke, Steve, and Kurt Schuler (1994). Currency Boards for Developing Countries. A Handbook, International Center for Economic Growth, ICS Press, San Francisco.

Havrylyshyn, Oleh, M. Miller and W. Perraudin (1994). "Deficits, Inflation and the Political Economy of Ukraine," Economic Policy, No. 19, October.

Helliwell, John F. (1994). "Empirical Linkages Between Democracy and Economic Growth," in British Journal of Political Science, Vol. 24, part 2, pp. 225-248.

Horst, Siebert (ed.) (1993). Overcoming the Transformation Crisis, Institut fur Weltwirtschaft an der Universitat Kiel.

Hughes, Gordon and Paul Hare (1994). The International Competitiveness of Industries in Bulgaria, Czechoslovakia, Hungary, and Poland, Oxford Economic Papers 46, pgs. 200-221.

Hung, Nguyen Manh (ed.) (1992). The Challenges of Vietnam's Reconstruction, Indochina Institute, George Mason University, Fairfax, Virginia, and East-West Center, Honolulu.

Ickes, Barry and Randi Ryterman (1993). "From Enterprise to Firm: Notes for a Theory of the Enterprise in Transition," Chapter 5 in The Postcommunist Economic Transformation, Robert Campbell (ed.), Westview Press, Boulder.

Inkeles, Alex (1990). "Introduction: On Measuring Democracy," in Studies in Comparative International Development, Vol. 25, No. 1, pp.3-6.

International Monetary Fund (1994). World Economic Outlook: World Economic and Financial Surveys, Washington, D.C., October. 
(1995). World Economic Outlook: World Outlook Economic and Financial

Surveys, Washington, D.C., May.

. "Financial Relations Among Countries of the Former Soviet Union," in IMF Economic Review, No. 1.

Jackman, Richard (1994). "Economic Policy and Employment in the Transition Economies of Central and Eastern Europe: What Have We Learned?," in International Labour Review, Vol. 133, No. 3, pp. 327-345.

Karatnycky, Adrian (1995). "Democracies on the Rise, Democracies at Risk," in Freedom Review. January/February, Freedom House, pp. 5-22.

Kierzkowski, Henryk, Edmund Phelps, and Gylfi Zoega (1994). "Mechanisms of Economic Collapse and Growth in Eastern Europe," PPRG Discussion Paper No. 30, Polish Policy Research Group, Warsaw.

Kopits, George and Erik Offerdal (1994). "Fiscal Policy in Transition Economies: A Major Challenge," in Finance and Development, Vol. 31, No. 4, pp. 10-13, International Monetary Fund/The World Bank, Washington, D.C., December.

Kornai, Janos (1993a). "Transformational Recession: A General Phenomenon Examined through the Example of Hungary's Development," Economie Applique, Vol. 46, No. 2, pp. 181-227.

Kornai, Janos (1993b). "The Evolution of Financial Discipline under the Postsocialist System," Kyklos, Vol. 46, No. 3.

Lane, Timothy, and Elias Dinopoulos (1991). "Fiscal Constraints on Market Oriented Reform in a Socialist Economy," Working Paper, Research Department, International Monetary Fund, July.

Leijonhufvud, Axel (1994). "The Macroeconomic Dilemma of Russia," Commencement Lecture at the Central European University, Prague, August.

McKinnon, Ronald I (1994). "Financial Growth and Macroeconomic Stability in China, 1978-1992: Implications for Russia and Other Transitional Economies," Journal of Comparative Economics, Vol. 18, No. 3, pp. 438-470, June.

Milanovic, Branko (1995). "Poverty, Inequality and Social Policy in Transition Economies," Research Project on Income Distribution during the Transition, Paper No. 9, Policy Research Department, Washington, D.C. April. 
Ofer, Gur (1987). "Soviet Economic Growth: 1928-85," Journal of Economic Literature, Vol. 25, No. 4, pp. 1767-1833.

Portes, Richard (ed.) (1993). Economic Transformation in Central Europe: A Progress Report, Centre for Economic Policy Research, London.

Rona-Tas, Akos (1994). "The First Shall be Last? Entrepreneurship and Communist Cadres in the Transition from Socialism," in American Journal of Sociology, Vol. 100, No. 1 pp. 40-69.

Rostowski, Jacek. "Systemic Requirements for Monetary Stability in Eastern Europe and the FSU," IMF Working Paper, WP/94/24.

Saavalainen, T.O. (1995). "Stabilization in the Baltic Countries: A Comparative Analysis," IMF Working Paper, WP/95/44.

Sachs, Jeffrey (1994). "Russia's Struggle with Stabilization: Conceptual Issues and Evidence," Paper presented at the World Bank's Annual Conference on Development Economics.

and Wing Thye Woo, (1994). "Structural Factors in the Economic Reforms of China, Eastern Europe, and the Former Soviet Union," Economic Policy, Vol. 18, April.

Sahay, Ratna and Carlos Vegh, (1995). "Inflation and Stabilization in Transition Economies: A Comparison with Market Economies," IMF Working Paper, WP/95/8.

(1995). "Dollarization in Transition Economies: Evidence and Policy Implications," Unpublished, March.

Sargent, Thomas (1982). "The Ends of Four Big Inflations," in Robert Hall (ed.), Inflation, Causes and Effects, National Bureau of Economic Research, published by The University of Chicago Press, Chicago.

Tanzi, Vito (ed.) (1992). Fiscal Policies in Economies in Transition, International Monetary Fund, Washington, D.C.

Tanzi, Vito (1993). "The Budget Deficit in Transition: A Cautionary Note," in IMF Staff Papers, Vol. 40, No. 3, pp. 697-707, International Monetary Fund, Washington, D.C., September.

Taylor, Lance (1994). "Market Met Its Match: Lessons For Future From The Transition's Initial Years 1994," Journal of Comparative Economics, Vol.19, pp. 64-87. 
Thuyet, Van Pham (1995). "Legal Framework and Private Sector Development in Transitional Economies: The Case of Vietnam, " mimeo, Policy Research Department, World Bank.

Vegh, Carlos A (1992). "Stopping High Inflation: An Analytical Overview," IMF Staff Papers, Vol. 39, No. 3, pp. 626-695, September.

Windell, James, Richard Anker and Gyorgy Sziraczki (1995) "Kyrghzstan: Enterprise Restructuring and Labor Shedding in a Free-Fall Economy, 1991-1994, " Labor Market Paper No. 5, Employment Department, International Labor Office, Geneva.

Wing, Thye Woo (1994). "The Art of Reforming Centrally Planned Economies: Comparing China, Poland, and Russia," Journal of Comparative Economics, Vol. 18, No. 3, pp. 276-309, June.

World Bank. "Uzbekistan: An Agenda for Reform," Washington, D.C.

World Bank (1995). "Kyrgyz Republic Economic Report," Washington, D.C.

Yusuf, Shahid (1994). "China's Macroeconomic Performance and Management during Transition," Journal of Economic Perspectives, Vol. 8, No. 2, pp. 71-92, June. 


\section{APPENDIX \\ THE LIBERALIZATION INDEX AND HOW IT WAS DERIVED}

The attached table gives the Cumulative Liberalization Index (CLI), as well as the annual Liberalization Index (LI) and its components, for the 28 countries included in this study. It also shows, in the last column, the CLI normalized to reflect the number of Poland-equivalent reform years; this normalized CLI is used in the switching regime regressions in Section V.

An extensive process of consultation was followed in assigning annual country rankings for each component of the LI. First, the authors proposed rankings on the basis of their own knowledge and country reports. Second, the authors consulted World Bank and other country specialists on a country's pace of reforms over time and on its ranking relative to other transition countries known by the specialist. Third, revised rankings were submitted to a second round of comments from relatively senior experts who have a comparative perspective across a wider range of countries. And fourth, for the 25 countries in CEE and FSU, a further adjustment was made based on the transition indicators in the EBRD's 1994 Transition Report (Table 2.1) and the accompanying text. This adjustment was designed to introduce further objectivity into the country rankings; the accompanying matrix describes the correspondence between the transition indicators and the LI components.

In the final analysis, the rankings reflect the authors' judgment. Individual errors in judgment no doubt exist, but we believe the general picture of economic liberalization suggested by the country rankings over time is reasonable. 


\section{Correspondence of the 1994 Liberalization Index Components with EBRD Report Indicators}

\begin{tabular}{|c|c|c|c|c|c|}
\hline \multirow[b]{2}{*}{1994 LI Components } & \multicolumn{5}{|c|}{ EBRD Indicators 1994} \\
\hline & $\begin{array}{c}\text { Price } \\
\text { Liberalization and } \\
\text { Competition }\end{array}$ & $\begin{array}{l}\text { Trade and } \\
\text { Foreign } \\
\text { Exchange } \\
\text { System }\end{array}$ & $\begin{array}{l}\text { Large-scale } \\
\text { Privatization }\end{array}$ & $\begin{array}{l}\text { Small-scale } \\
\text { Privatization }\end{array}$ & $\begin{array}{l}\text { Banking } \\
\text { Reform }\end{array}$ \\
\hline I (internal prices) & $x^{\underline{a} /}$ & & & & \\
\hline E (external markets) & & $x^{\underline{b} /}$ & & & \\
\hline$P($ private sector entry) $\underline{c}$ & & & $x$ & $x$ & $x$ \\
\hline
\end{tabular}

Source: EBRD, Transition Report, 1994.

a/ 1 is further differentiated to reflect the status of state trading.

$\mathrm{b} / \mathrm{E}$ is further differentiated on basis of Chapter 8 in the EBRD report.

$\mathrm{c} / \mathbf{P}$ is calculated as the sum of the indicator values, where banking reform is used as a proxy for a favorable environment for private sector development. 
Appendix: Indices of Liberalization

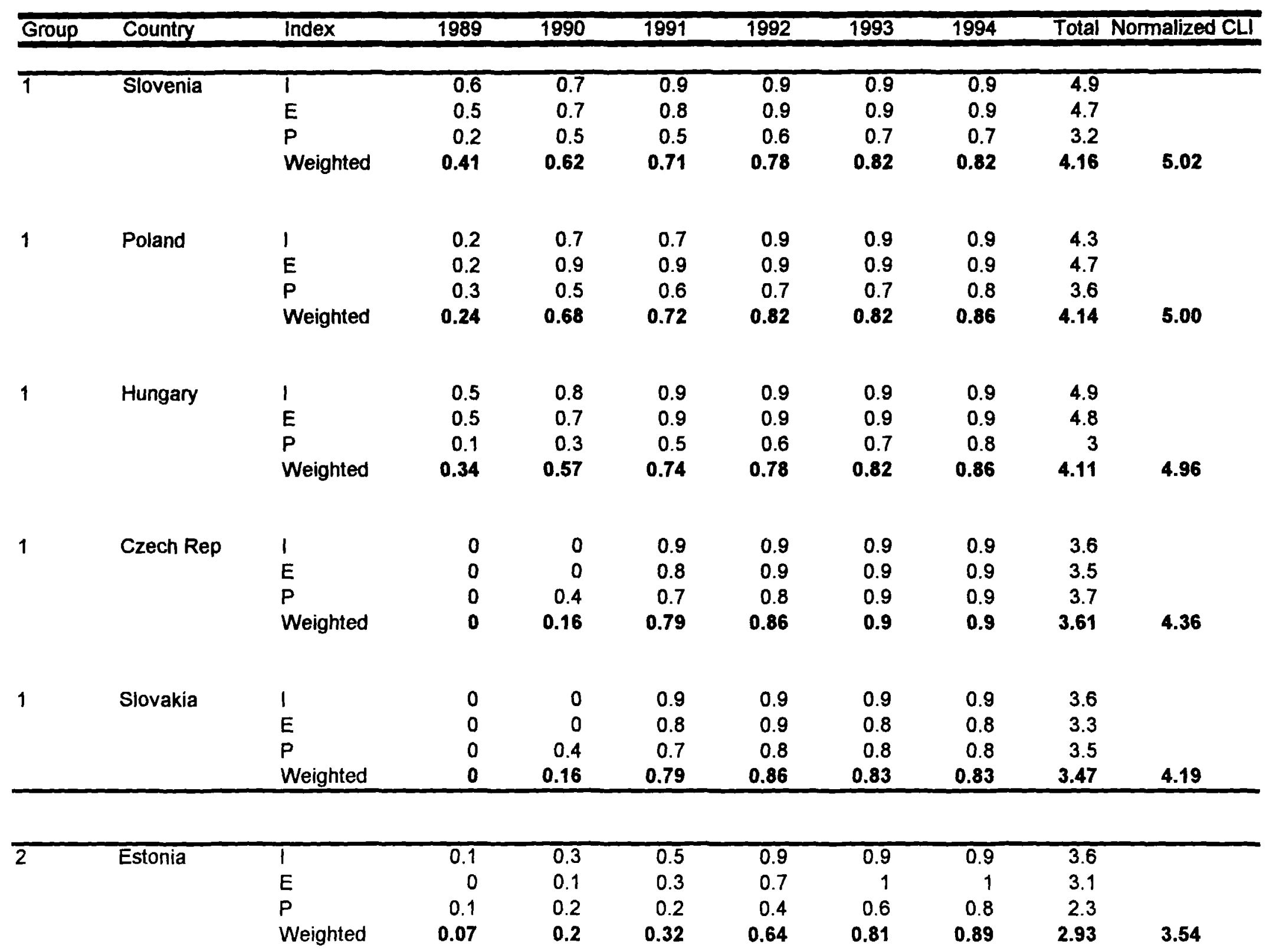


Appendix: Indices of Liberalization

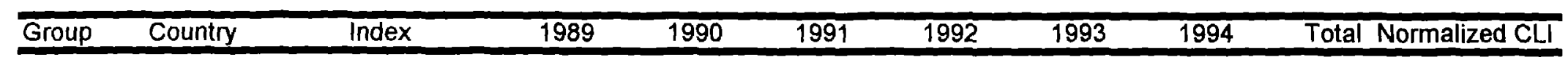

$2 \quad$ Bulgaria

$\begin{array}{lrrrrrrr}\text { I } & 0 & 0 & 0.9 & 0.9 & 0.9 & 0.8 & 3.5 \\ \mathrm{E} & 0.3 & 0.5 & 0.9 & 0.9 & 0.9 & 0.8 & 4.3 \\ \mathrm{P} & 0.1 & 0.1 & 0.2 & 0.3 & 0.3 & 0.4 & 1.4 \\ \text { Weighted } & \mathbf{0 . 1 3} & \mathbf{0 . 1 9} & \mathbf{0 . 6 2} & \mathbf{0 . 6 6} & \mathbf{0 . 6 6} & \mathbf{0 . 6 4} & \mathbf{2 . 9}\end{array}$

3.50

$2 \quad$ Lithuania

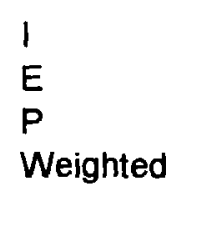

0
0
0.1
0.04

0.3
0
0.1
0.13

0.5
0.2
0.3
$\mathbf{0 . 3 3}$

0.8
0.5
0.4
0.55

$\begin{array}{rrr}0.9 & 0.9 & 3.4 \\ 0.9 & 1 & 2.6 \\ 0.6 & 0.8 & 2.3 \\ 0.78 & 0.89 & 2.72\end{array}$

$2 \quad$ Latvia

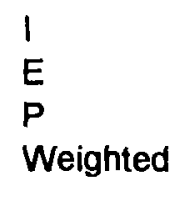

$\begin{array}{rrrr}0 & 0.3 & 0.5 & 0.8 \\ 0 & 0 & 0.2 & 0.5 \\ 0.1 & 0.1 & 0.2 & 0.3 \\ 0.04 & 0.13 & 0.29 & 0.51\end{array}$

0.8
0.5
0.3

$\begin{array}{rrr}0.9 & 0.9 & 3.4 \\ 0.8 & 1 & 2.5 \\ 0.4 & 0.6 & 1.7 \\ 0.67 & 0.81 & 2.45\end{array}$

2.96

$2 \quad$ Albania

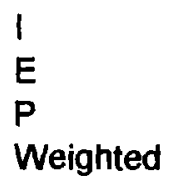

$\begin{array}{ll}0 & 0 \\ 0 & 0 \\ 0 & 0 \\ 0 & 0\end{array}$

$\begin{array}{lrrrrr}0 & 0.2 & 0.9 & 0.9 & 0.9 & 2.9 \\ 0 & 0.2 & 0.9 & 0.9 & 0.9 & 2.9 \\ 0 & 0.3 & 0.3 & 0.4 & 0.4 & 1.4 \\ 0 & 0.24 & 0.66 & 0.7 & 0.7 & 2.3\end{array}$

2.78

2

Romania

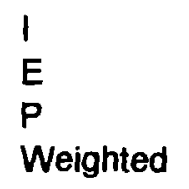

$\begin{array}{lr}0 & 0.5 \\ 0 & 0.1 \\ 0 & 0.1 \\ 0 & 0.22\end{array}$

$\begin{array}{rrrrrr}0.5 & 0.5 & 0.5 & 0.7 & 0.8 & 3 \\ 0.1 & 0.3 & 0.6 & 0.7 & 0.8 & 2.5 \\ 0.1 & 0.3 & 0.3 & 0.4 & 0.5 & 1.6 \\ 0.22 & 0.36 & 0.45 & 0.58 & 0.68 & 2.29\end{array}$

2.77

2

Mongolia

\begin{tabular}{lrrrrrrr} 
I & 0 & 0 & 0.4 & 0.5 & 0.6 & 0.7 & 2.2 \\
E & 0 & 0 & 0.4 & 0.4 & 0.5 & 0.6 & 1.9 \\
P & 0 & 0 & 0.5 & 0.7 & 0.7 & 0.7 & 2.6 \\
Weighted & 0 & 0 & 0.44 & 0.55 & 0.61 & 0.67 & 2.27 \\
\hline
\end{tabular}


Appendix: Indices of Liberalization

\begin{tabular}{|c|c|c|c|c|c|c|c|c|c|c|}
\hline Group & Country & Index & 1989 & 1990 & 1991 & 1992 & 1993 & 1994 & Total & Normalized CLI \\
\hline \multirow[t]{4}{*}{3} & Russia & $T$ & 0 & $\overline{0}$ & 0.1 & 0.6 & 0.7 & 0.7 & 2.1 & \\
\hline & & $E$ & 0 & 0 & 0.1 & 0.5 & 0.6 & 0.7 & 1.9 & \\
\hline & & $P$ & 0.1 & 0.1 & 0.1 & 0.4 & 0.5 & 0.6 & 1.8 & \\
\hline & & Weighted & 0.04 & 0.04 & 0.1 & 0.49 & 0.59 & 0.66 & 1.92 & 2.32 \\
\hline \multirow[t]{4}{*}{3} & Kyrgyzstan & 1 & 0 & 0 & 0 & 0.3 & 0.6 & 0.8 & 1.7 & \\
\hline & & $E$ & 0 & 0 & 0 & 0.4 & 0.6 & 0.8 & 1.8 & \\
\hline & & $\vec{P}$ & 0.1 & 0.1 & 0.1 & 0.3 & 0.6 & 0.7 & 1.9 & \\
\hline & & Weighted & 0.04 & 0.04 & 0.04 & 0.33 & 0.6 & 0.76 & 1.81 & 2.19 \\
\hline \multirow[t]{4}{*}{3} & Moldova & 1 & 0 & 0 & 0.1 & 0.5 & 0.7 & 0.7 & 2 & \\
\hline & & $E$ & 0 & 0 & 0.1 & 0.5 & 0.6 & 0.6 & 1.8 & \\
\hline & & $P$ & 0.1 & 0.1 & 0.1 & 0.2 & 0.3 & 0.4 & 1.2 & \\
\hline & & Weighted & 0.04 & 0.04 & 0.1 & 0.38 & 0.51 & 0.55 & 1.62 & 1.96 \\
\hline \multirow[t]{4}{*}{3} & Kazakhstan & 1 & 0 & 0 & 0.1 & 0.5 & 0.5 & 0.5 & 1.6 & \\
\hline & & $E$ & 0 & 0 & 0.1 & 0.4 & 0.4 & 0.4 & 1.3 & \\
\hline & & $P$ & 0.1 & 0.1 & 0.2 & 0.2 & 0.2 & 0.3 & 1.1 & \\
\hline & & Weighted & 0.04 & 0.04 & 0.14 & 0.35 & 0.35 & 0.39 & 1.31 & 1.58 \\
\hline \multirow[t]{4}{*}{4} & Uzbekistan & $T$ & $\overline{0}$ & 0 & 0 & $\overline{0.4}$ & 0.4 & 0.5 & 1.3 & \\
\hline & & $E$ & 0 & 0 & 0 & 0.2 & 0.2 & 0.4 & 0.8 & \\
\hline & & $P$ & 0.1 & 0.1 & 0.1 & 0.2 & 0.3 & 0.4 & 1.2 & \\
\hline & & Weighted & 0.04 & 0.04 & 0.04 & 0.26 & 0.3 & 0.43 & 1.11 & 1.34 \\
\hline \multirow[t]{4}{*}{4} & Belarus & 1 & 0 & 0 & 0.1 & 0.2 & 0.3 & 0.4 & 1 & \\
\hline & & $E$ & 0 & 0 & 0.1 & 0.2 & 0.4 & 0.4 & 1.1 & \\
\hline & & $P$ & 0.1 & 0.1 & 0.1 & 0.2 & 0.3 & 0.3 & 1.1 & \\
\hline & & Weighted & 0.04 & 0.04 & 0.1 & 0.2 & 0.33 & 0.36 & 1.07 & 1.29 \\
\hline
\end{tabular}


Appendix: Indices of Liberalization

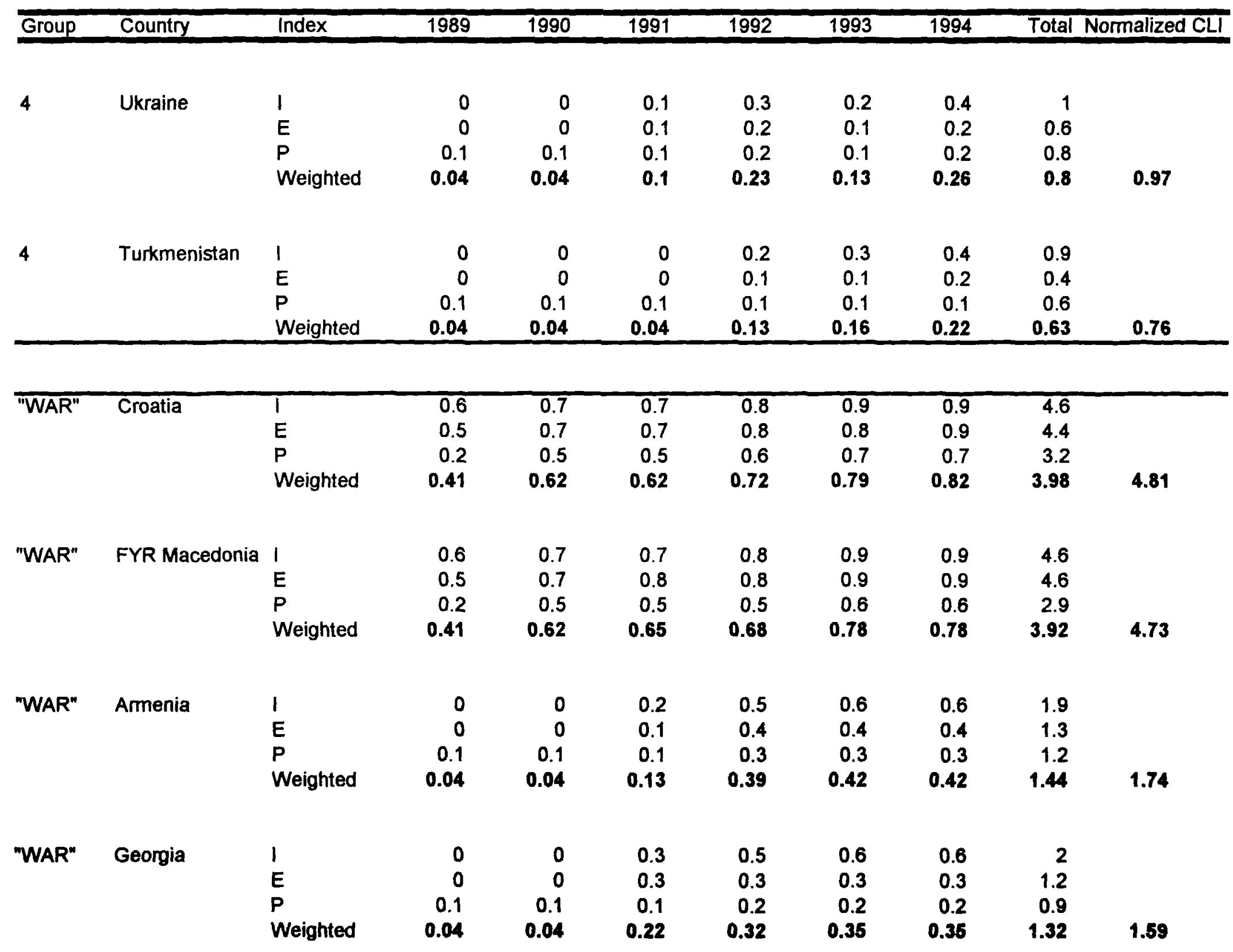




\section{Appendix: Indices of Liberalization}

\begin{tabular}{|c|c|c|c|c|c|c|c|c|c|c|}
\hline Group & Country & Index & 1989 & 1990 & 1991 & 1992 & 1993 & 1994 & Total & Normalized CLI \\
\hline \multirow[t]{4}{*}{ "WAR" } & Azerbaijan & I & 0 & 0 & 0 & 0.5 & 0.7 & 0.7 & 1.9 & \\
\hline & & $E$ & 0 & 0 & 0 & 0.2 & 0.2 & 0.2 & 0.6 & \\
\hline & & $P$ & 0.1 & 0.1 & 0.1 & 0.1 & 0.1 & 0.2 & 0.7 & \\
\hline & & Weighted & 0.04 & 0.04 & 0.04 & 0.25 & 0.31 & 0.35 & 1.03 & 1.24 \\
\hline \multirow[t]{4}{*}{ "WAR" } & Tajikistan & 1 & 0 & 0 & 0.1 & 0.4 & 0.5 & 0.5 & 1.5 & \\
\hline & & $E$ & 0 & 0 & 0 & 0 & 0.1 & 0.1 & 0.2 & \\
\hline & & $P$ & 0.1 & 0.1 & 0.2 & 0.2 & 0.2 & 0.3 & 1.1 & \\
\hline & & Weighted & 0.04 & 0.04 & 0.11 & 0.2 & 0.26 & 0.3 & 0.95 & 1.15 \\
\hline East & Viet Nam & 1 & 0.6 & 0.6 & 0.7 & 0.8 & 0.8 & 0.8 & 4.3 & \\
\hline \multirow[t]{3}{*}{ Aisa } & & E & 0.5 & 0.5 & 0.5 & 0.5 & 0.5 & 0.6 & 3.1 & \\
\hline & & $P$ & 0.5 & 0.5 & 0.5 & 0.5 & 0.5 & 0.5 & 3 & \\
\hline & & Weighted & 0.53 & 0.53 & 0.56 & 0.59 & 0.59 & 0.62 & 3.42 & 4.13 \\
\hline East & China & 1 & 0.5 & 0.6 & 0.6 & 0.6 & 0.7 & 0.7 & 3.7 & \\
\hline \multirow[t]{3}{*}{ Asia } & & $E$ & 0.5 & 0.5 & 0.5 & 0.5 & 0.5 & 0.6 & 3.1 & \\
\hline & & $P$ & 0.4 & 0.4 & 0.4 & 0.4 & 0.5 & 0.5 & 2.6 & \\
\hline & & Weighted & 0.46 & 0.49 & 0.49 & 0.49 & 0.56 & 0.59 & 3.08 & 3.72 \\
\hline
\end{tabular}


TABLE 1: FROM PLAN TO MARKET:

The Common Legacy

and Systemic Change during Transition

Common Legacy

1. Macrobalance by direct control

2. Coordination through plans

3. Little private ownership

4. Distorted relative prices
Changes Occurring

during Transition

Macroeconomic destabilization

Output declines resulting from disruption

in the coordinating mechanism

Output gains from private ownership and private sector growth

Microeconomic and sectoral reallocations 
TABLE 2:

Liberalization, Growth and Inflation, 1989-94

\begin{tabular}{|c|c|c|c|c|c|c|c|}
\hline Group & Countries & $\begin{array}{c}\text { CLI } \\
1994\end{array}$ & $\begin{array}{l}\text { Av lib } \\
93 / 94\end{array}$ & $\begin{array}{l}\text { Av infl } \\
93 / 94\end{array}$ & $\begin{array}{c}\text { Av growth } \\
93 / 94 \\
\end{array}$ & $\begin{array}{c}\text { 93/94 GDP } \\
\text { /89 GDP }\end{array}$ & $\begin{array}{c}\text { Lowest level } \\
\text { of GDP/89 GDP } \\
\end{array}$ \\
\hline Advanced & Slovenia & 4.16 & 0.82 & 26 & 3.0 & 84 & 81 \\
\hline \multirow[t]{5}{*}{ Reformers } & Poland & 4.14 & 0.84 & 34 & 4.2 & 88 & 82 \\
\hline & Hungary & 4.11 & 0.84 & 21 & 0.0 & 81 & 80 \\
\hline & Czech Rep & 3.61 & 0.90 & 16 & 0.8 & 81 & 80 \\
\hline & Slovakia & 3.53 & 0.86 & 19 & 0.4 & 79 & 77 \\
\hline & Averages & 3.91 & 0.85 & 23 & 1.7 & 83 & 80 \\
\hline High & Bulgaria & 2.96 & 0.68 & 81 & -1.4 & 73 & 73 \\
\hline Intermediate & Estonia & 2.93 & 0.85 & 69 & 0.9 & 69 & 67 \\
\hline \multirow[t]{6}{*}{ Reformers } & Lithuania & 2.62 & 0.79 & 231 & -7.3 & 44 & 44 \\
\hline & Latvia & 2.39 & 0.71 & 73 & -4.4 & 60 & 59 \\
\hline & Romania & 2.35 & 0.66 & 194 & 2.2 & 69 & 67 \\
\hline & Albania & 2.30 & 0.70 & 57 & 9.5 & 74 & 65 \\
\hline & Mongolia & 2.27 & 0.64 & 164 & 0.6 & 84 & 83 \\
\hline & Averages & 2.55 & 0.72 & 124 & 0.03 & 68 & 65 \\
\hline Low & Russia & 1.92 & 0.63 & 558 & -13.5 & 57 & 52 \\
\hline Intermediate & Kyrgyzstan & 1.81 & 0.68 & 744 & -13.2 & 61 & 57 \\
\hline \multirow[t]{3}{*}{ Reformers } & Moldova & 1.62 & 0.53 & 558 & -17.0 & 53 & 46 \\
\hline & Kazakhstan & 1.31 & 0.37 & 1870 & -18.5 & 57 & 49 \\
\hline & Averages & 1.67 & 0.55 & 933 & -15.6 & 57 & 51 \\
\hline Slow & Uzbekistan & 1.11 & 0.37 & 640 & -2.5 & 89 & 88 \\
\hline \multirow[t]{4}{*}{ Reformers } & Belarus & 1.07 & 0.35 & 1694 & -16.6 & 73 & 64 \\
\hline & Ukraine & 0.80 & 0.20 & 2789 & -18.6 & 56 & 48 \\
\hline & Turkmenistan & 0.63 & 0.19 & 2751 & -15.0 & 69 & 62 \\
\hline & Averages & 0.90 & 0.27 & 1968 & -13.2 & 72 & 66 \\
\hline Affected & Croatia & 4.02 & 0.83 & 807 & -0.7 & 69 & 68 \\
\hline \multirow[t]{6}{*}{ by War } & FYR Macedonia & 3.92 & 0.78 & 157 & -10.7 & 57 & 55 \\
\hline & Armenia & 1.44 & 0.42 & 4595 & -7.4 & 38 & 38 \\
\hline & Georgia & 1.32 & 0.35 & 10563 & -24.6 & 24 & 23 \\
\hline & Azerbaijan & 1.03 & 0.33 & 1167 & -17.7 & 50 & 44 \\
\hline & Tajikistan & 0.95 & 0.28 & 1324 & -26.3 & 35 & 30 \\
\hline & Averages & 2.11 & 0.50 & 3102 & -14.5 & 45 & 34 \\
\hline East & Viet Nam & 3.42 & 0.78 & 10 & 8.5 & 145 & 100 \\
\hline \multirow[t]{2}{*}{ Asia } & China & 3.08 & 0.64 & 13 & 11.7 & 157 & 100 \\
\hline & Averages & 3.25 & 0.71 & 11 & 10.1 & 151 & 100 \\
\hline
\end{tabular}

Note: $C L I=$ cumulative liberalization index. 
TABLE 3:

Inflation Experience by Reform Group, 1989-94

\begin{tabular}{|c|c|c|c|c|c|c|c|c|c|}
\hline \multirow[b]{2}{*}{ Group } & \multirow[b]{2}{*}{ Countries } & \multirow{2}{*}{$\begin{array}{r}\text { Cumul } \\
\text { Lib Index } \\
\end{array}$} & \multirow[b]{2}{*}{1989} & \multicolumn{4}{|c|}{ Inflation } & \multicolumn{2}{|c|}{$\begin{array}{r}\text { Geometric } \\
\text { average }\end{array}$} \\
\hline & & & & 1990 & 1991 & 1992 & 1993 & 1994 & \\
\hline Advanced & Slovenia & 4.2 & 1306.0 & 549.7 & 117.7 & 201.0 & 32.0 & 19.8 & 213.3 \\
\hline \multirow[t]{5}{*}{ Reformers } & Poland & 4.1 & 251.0 & 586.0 & 70.3 & 43.0 & 35.3 & 32.2 & 117.2 \\
\hline & Hungary & 4.1 & 17.0 & 29.0 & 34.2 & 22.9 & 22.5 & 19.0 & 24.0 \\
\hline & Czech Republic & 3.6 & 2.3 & 10.8 & 56.7 & 11.1 & 20.8 & 10.2 & 17.5 \\
\hline & Slovak Republic & 3.5 & 0.0 & 10.8 & 61.2 & 10.1 & 23.0 & 14.0 & 18.4 \\
\hline & Averages & 3.9 & 315.3 & 237.3 & 68.0 & 57.6 & 26.7 & 19.0 & 78.1 \\
\hline High & Bulgaria & 3.0 & 6.0 & 22.0 & 333.5 & 82.0 & 72.8 & 89.0 & 79.4 \\
\hline Intermediate & Estonia & 2.9 & 6.1 & 23.1 & 210.6 & 1069.0 & 89.0 & 48.0 & 125.8 \\
\hline \multirow[t]{6}{*}{ Reformers } & Lithuania & 2.6 & 2.1 & 8.4 & 224.7 & 1020.3 & 390.2 & 72.0 & 164.1 \\
\hline & Latvia & 2.4 & 4.7 & 10.5 & 124.4 & 951.2 & 109.0 & 36.0 & 106.5 \\
\hline & Romania & 2.4 & 1.1 & 5.1 & 174.5 & 210.9 & 256.0 & 131.0 & 105.2 \\
\hline & Albania & 2.3 & 0.0 & 0.0 & 35.5 & 225.9 & 85.0 & 28.0 & 47.9 \\
\hline & Mongolia & 2.3 & 0.0 & 0.0 & 208.6 & 321.0 & 183.0 & 145.0 & 111.7 \\
\hline & Averages & 2.5 & 2.9 & 9.9 & 187.4 & 554.3 & 169.3 & 78.4 & 105.8 \\
\hline Low & Russia & 1.9 & 2.2 & 5.6 & 92.7 & 1353.0 & 896.0 & 220.0 & 214.3 \\
\hline Intermediate & Kyrgyz Republic & 1.8 & 0.0 & 3.0 & 85.0 & 854.6 & 1208.7 & 280.0 & 211.0 \\
\hline \multirow[t]{3}{*}{ Reformers } & Moldova & 1.6 & 0.0 & 4.2 & 98.0 & 1276.0 & 789.0 & 327.0 & 220.2 \\
\hline & Kazakhstan & 1.3 & 0.0 & 4.2 & 91.0 & 1610.0 & 1760.0 & 1980.0 & 385.9 \\
\hline & Averages & 1.7 & 0.6 & 4.3 & 91.7 & 1273.4 & 1163.4 & 701.8 & 257.8 \\
\hline Slow & Uzbekistan & 1.1 & 0.7 & 3.1 & 82.2 & 645.0 & 534.0 & 746.0 & 201.8 \\
\hline \multirow[t]{4}{*}{ Reformers } & Belarus & 1.1 & 1.7 & 4.5 & 83.5 & 969.0 & 1188.0 & 2200.0 & 328.3 \\
\hline & Ukraine & 0.8 & 2.0 & 4.0 & 91.2 & 1210.0 & 4735.0 & 842.0 & 379.2 \\
\hline & Turkmenistan & 0.6 & 2.1 & 4.6 & 102.5 & 492.9 & 3102.0 & 2400.0 & 366.2 \\
\hline & Averages & 0.9 & 1.6 & 4.1 & 89.9 & 829.2 & 2389.8 & 1547.0 & 318.9 \\
\hline \multirow{7}{*}{$\begin{array}{l}\text { Affected } \\
\text { by War }\end{array}$} & Croatia & 4.0 & 2520.5 & 135.6 & 249.5 & 938.2 & 1516.0 & 98.0 & 544.5 \\
\hline & FYR Macedonia & 3.9 & 1246.0 & 120.5 & 229.7 & 1925.2 & 248.0 & 65.0 & 374.3 \\
\hline & Armenia & 1.4 & 0.0 & 10.3 & 100.0 & 825.0 & 3732.0 & 5458.0 & 492.9 \\
\hline & Georgia & 1.3 & 0.0 & 3.3 & 78.5 & 913.0 & 3126.0 & 18000.0 & 591.2 \\
\hline & Azerbaijan & 1.0 & 0.0 & 7.8 & 105.6 & 616.0 & 833.0 & 1500.0 & 265.1 \\
\hline & Tajikistan & 1.0 & 0.0 & 4.0 & 111.6 & 1157.0 & 2195.0 & 452.0 & 289.7 \\
\hline & Averages & 2.1 & 627.8 & 46.9 & 145.8 & 1062.4 & 1941.7 & 4262.2 & 426.3 \\
\hline East & Viet Nam & 3.4 & 76.0 & 67.5 & 67.6 & 17.5 & 5.2 & 14.4 & 38.3 \\
\hline \multirow{2}{*}{ Asia } & China & 3.1 & 17.5 & 1.6 & 3.0 & 5.4 & 13.0 & 12.0 & 8.6 \\
\hline & Averages & 3.3 & 46.8 & 34.6 & 35.3 & 11.5 & 9.1 & 13.2 & 23.4 \\
\hline
\end{tabular}

Sources: World Bank, IMF 
TABLE 4:

Switching Regressions, 1989-94

\begin{tabular}{|c|c|c|c|c|c|c|}
\hline & \multicolumn{3}{|c|}{ Growth } & \multicolumn{3}{|c|}{ Log Inflation } \\
\hline & \multicolumn{2}{|c|}{ Coefficients } & \multirow{2}{*}{$\frac{\text { Profile }-\underline{y}}{1.6}$} & \multicolumn{2}{|c|}{ Coefficients } & \multirow{2}{*}{$\frac{\text { Profile }}{1.6}$} \\
\hline 5 years before reform & 14.2 & (6.7) & & -4.4 & $(10.6)$ & \\
\hline 4 years before reform & 8.3 & (3.7) & -4.3 & -4.1 & (9.3) & 1.9 \\
\hline 3 years before reform & 2.5 & (1.1) & -10.1 & -1.5 & (3.2) & 4.5 \\
\hline 2 years before reform & -6.6 & (2.5) & -19.2 & 0.4 & $(0.7)$ & 6.4 \\
\hline 1 year before reform & 2.8 & $(0.8)$ & -9.8 & 1 & (1.5) & 7.0 \\
\hline 1st year of reform (intercept) & -12.6 & (8.3) & -12.6 & 6 & (20.2) & 6.0 \\
\hline 2nd year of reform & 5.6 & (2.5) & -7.0 & -0.7 & $(1.6)$ & 5.3 \\
\hline 3 rd year of reform & 11.3 & (4.5) & -1.3 & -2.1 & (4.3) & 3.9 \\
\hline 4th year of reform & 13.8 & (4.7) & 1.2 & -2.3 & $(4.0)$ & 3.7 \\
\hline 5th year of reform & 15.5 & (4.2) & 2.9 & -2.9 & (4.0) & 3.1 \\
\hline WAR & -9 & (4.7) & -21.6 & 1.4 & (3.7) & 7.4 \\
\hline R-square & 0.51 & & & 0.65 & & \\
\hline Adjusted R-square & 0.48 & & & 0.63 & & \\
\hline
\end{tabular}

a/ Regressions are based on 26 observations; $t$ statistics are shown in parenthesis.

b/ Coefficient plus intercept: This is predicted annual growth or inflation rate. 
TABLE 5:

Net External Financing and Fixed Investment

\begin{tabular}{|c|c|c|c|c|c|c|}
\hline \multirow[b]{2}{*}{ Group } & \multirow[b]{2}{*}{ Countries } & \multirow[b]{2}{*}{$\begin{array}{c}\text { Cumul } \\
\text { Lib Index } \\
\end{array}$} & \multicolumn{2}{|c|}{ Current Account a } & \multicolumn{2}{|c|}{ Fixed Investment } \\
\hline & & & $\begin{array}{r}\text { Average } \\
1989-94 \\
\end{array}$ & $\begin{array}{c}\text { Level } \\
1994 \\
\end{array}$ & $\begin{array}{l}\text { Change } \\
1989-94 \\
\end{array}$ & $\begin{array}{l}\text { Level } \\
1994 \\
\end{array}$ \\
\hline Advanced & Slovenia & 4.16 & 3.4 & 4.0 & 1.0 & 19.0 \\
\hline \multirow[t]{5}{*}{ Reformers } & Poland & 4.14 & -1.0 & -1.0 & -0.8 & 15.6 \\
\hline & Hungary & 4.11 & -3.0 & -9.9 & 1.3 & 21.4 \\
\hline & Czech Republic & 3.61 & -0.5 & 0.0 & -5.6 & 20.4 \\
\hline & Slovak Republic & 3.53 & 0.7 & 5.8 & -14.3 & 15.4 \\
\hline & Averages & 3.91 & -0.1 & -0.2 & -3.7 & 18.4 \\
\hline High & Bulgaria & 2.96 & -2.5 & 1.4 & -7.3 & 18.8 \\
\hline Intermediate & Estonia & 2.93 & -1.8 & -4.4 & -6.0 & 23.0 \\
\hline \multirow[t]{6}{*}{ Reformers } & Lithuania & 2.62 & 3.6 & -4.7 & -14.0 & 18.0 \\
\hline & Latvia $\mathbf{b} /$ & 2.39 & 0.4 & -2.0 & -19.8 & 11.2 \\
\hline & Romania & 2.35 & -3.4 & -2.4 & -9.0 & 21.0 \\
\hline & Albania & 2.30 & -9.2 & -8.3 & -16.0 & 12.6 \\
\hline & Mongolia $\underline{b}$ & 2.27 & -19.5 & -5.6 & -23.1 & 20.9 \\
\hline & Averages & 2.55 & -4.6 & -3.7 & -13.6 & 17.9 \\
\hline Low & Russia & 1.90 & -0.1 & -0.3 & -8.0 & 24.0 \\
\hline Intermediate & Kyrgyz Republic & 1.81 & -15.9 & -19.6 & -19.0 & 13.0 \\
\hline \multirow[t]{3}{*}{ Reformers } & Moldova $\underline{\prime}$ & 1.62 & -4.8 & -9.2 & -4.0 & 14.0 \\
\hline & Kazakhstan $\subseteq$ l & 1.31 & -6.6 & -7.4 & -15.0 & 22.0 \\
\hline & Averages & 1.67 & -6.9 & -9.1 & -11.5 & 18.3 \\
\hline Slow & Uzbekistan & 1.11 & -0.8 & -2.0 & -5.0 & 26.0 \\
\hline \multirow[t]{4}{*}{ Reformers } & Belarus $\underline{b} /$ & 1.07 & -5.2 & -8.9 & 5.0 & 27.8 \\
\hline & Ukraine & 0.80 & -1.3 & -1.8 & n.a. & 3.0 \\
\hline & Turkmenistan $\subseteq$ I & 0.63 & 1.1 & -14.0 & -24.3 & 3.0 \\
\hline & Averages & 0.90 & -1.6 & -6.7 & -8.2 & 15.0 \\
\hline \multirow{7}{*}{$\begin{array}{c}\text { Affected } \\
\text { by War }\end{array}$} & Croatia & 4.02 & 2.4 & 0.3 & 0.5 & 14.3 \\
\hline & FYR Macedonia & 3.92 & -11.9 & -4.1 & 0.0 & 17.0 \\
\hline & Armenia & 1.44 & -16.0 & -36.6 & -16.5 & 10.0 \\
\hline & Georgia $\subseteq$ & 1.32 & -19.1 & -45.1 & -8.0 & 16.0 \\
\hline & Azerbaijan & 1.03 & -2.1 & -15.6 & -3.6 & 17.8 \\
\hline & Tajikistan & 0.95 & -20.0 & -14.0 & n.a. & n.a. \\
\hline & Averages & 2.11 & -13.8 & -27.8 & -5.5 & 15.0 \\
\hline & Viet Nam & 3.42 & 5.6 & -7.2 & 10.2 & 24.2 \\
\hline \multirow[t]{2}{*}{ Asia } & China & 3.08 & 1.8 & 7.2 & 8.9 & 36.5 \\
\hline & Averages & 3.25 & 3.7 & 0.0 & 9.6 & 30.5 \\
\hline
\end{tabular}

a/ For FSU, change is over 1991-94.

b/ For fixed investment, change is over 1989-93 and level for 1993.

c/ For fixed investment, change is over 1989-92 and level for 1992.

Source: IMF, World Bank 
TABLE 6:

Registered Unemployment through Transition (as percentage of labor force, end of year)

\begin{tabular}{|c|c|c|c|c|c|c|c|c|}
\hline Group & Country & CLI & 1989 & 1990 & 1991 & 1992 & 1993 & 1994 \\
\hline $\begin{array}{l}\text { Advanced } \\
\text { Reformers }\end{array}$ & $\begin{array}{l}\text { Sloveniaal } \\
\text { Poland } \\
\text { Hungary } \\
\text { Czech Republic } \\
\text { Slovakia } \\
\text { Averages }\end{array}$ & $\begin{array}{l}4.16 \\
4.14 \\
4.11 \\
3.61 \\
3.53 \\
3.91 \\
\end{array}$ & $\begin{array}{l}2.9 \\
0.1 \\
0.3 \\
0.0 \\
0.0 \\
0.7\end{array}$ & $\begin{array}{l}4.7 \\
6.1 \\
2.5 \\
0.8 \\
1.5 \\
3.1\end{array}$ & $\begin{array}{c}8.2 \\
11.8 \\
8.0 \\
4.1 \\
11.8 \\
8.8 \\
\end{array}$ & $\begin{array}{c}11.1 \\
13.6 \\
12.3 \\
2.6 \\
10.4 \\
10.0 \\
\end{array}$ & $\begin{array}{c}14.5 \\
16.4 \\
12.1 \\
3.5 \\
14.4 \\
12.2 \\
\end{array}$ & $\begin{array}{c}14.5 \\
16.0 \\
10.9 \\
3.2 \\
14.8 \\
11.9 \\
\end{array}$ \\
\hline $\begin{array}{r}\text { High } \\
\text { Intermediate } \\
\text { Reformers }\end{array}$ & $\begin{array}{l}\text { Bulgaria } \\
\text { Estonia } \\
\text { Lithuania } \\
\text { Latvia } \\
\text { Romania } \\
\text { Albania } \\
\text { Averages } \\
\end{array}$ & $\begin{array}{l}2.96 \\
2.93 \\
2.62 \\
2.39 \\
2.35 \\
2.30 \\
2.59\end{array}$ & $\begin{array}{l}0.0 \\
0.0 \\
0.0 \\
0.0 \\
0.0 \\
1.9 \\
0.3\end{array}$ & $\begin{array}{l}1.5 \\
0.0 \\
0.0 \\
0.0 \\
0.0 \\
7.7 \\
1.5\end{array}$ & $\begin{array}{l}11.1 \\
0.1 \\
0.3 \\
0.1 \\
3.0 \\
8.6 \\
3.9\end{array}$ & $\begin{array}{c}15.3 \\
4.8 \\
1.3 \\
2.1 \\
8.4 \\
26.9 \\
9.8 \\
\end{array}$ & $\begin{array}{c}16.4 \\
8.8 \\
4.4 \\
5.3 \\
10.2 \\
28.9 \\
12.3 \\
\end{array}$ & \begin{tabular}{c|}
12.8 \\
8.1 \\
3.8 \\
6.5 \\
10.9 \\
19.5 \\
10.3 \\
\end{tabular} \\
\hline $\begin{array}{r}\text { Low } \\
\text { Intermediate } \\
\text { Reformers }\end{array}$ & $\begin{array}{l}\text { Russia } \\
\text { Kyrgyzstan } \\
\text { Moldova } \\
\text { Kazakhstan } \\
\text { Averages } \\
\end{array}$ & $\begin{array}{l}1.92 \\
1.81 \\
1.62 \\
1.31 \\
1.67 \\
\end{array}$ & $\begin{array}{l}0.0 \\
0.0 \\
0.0 \\
0.0 \\
0.0\end{array}$ & $\begin{array}{l}0.0 \\
0.0 \\
0.0 \\
0.0 \\
0.0\end{array}$ & $\begin{array}{l}0.1 \\
0.0 \\
0.0 \\
0.1 \\
0.1\end{array}$ & $\begin{array}{l}0.8 \\
0.1 \\
0.7 \\
0.5 \\
0.5\end{array}$ & $\begin{array}{l}1.1 \\
0.2 \\
0.8 \\
0.6 \\
0.7\end{array}$ & $\begin{array}{l}2.2 \\
0.7 \\
1.2 \\
1.0 \\
1.3\end{array}$ \\
\hline $\begin{array}{r}\text { Slow } \\
\text { Reformers }\end{array}$ & $\begin{array}{l}\text { Uzbekistan } \\
\text { Belarus } \\
\text { Ukraine } \\
\text { Turkmenistan } \\
\text { Averages }\end{array}$ & $\begin{array}{l}1.10 \\
1.07 \\
0.80 \\
0.63 \\
0.90\end{array}$ & $\begin{array}{l}0.0 \\
1.0 \\
0.0 \\
0.0 \\
0.3\end{array}$ & $\begin{array}{l}0.0 \\
1.0 \\
0.0 \\
0.0 \\
0.3\end{array}$ & $\begin{array}{l}0.0 \\
1.0 \\
0.0 \\
0.0 \\
0.3\end{array}$ & $\begin{array}{l}0.1 \\
0.5 \\
0.3 \\
0.0 \\
0.2\end{array}$ & $\begin{array}{l}0.2 \\
1.5 \\
0.4 \\
0.0 \\
0.5\end{array}$ & $\begin{array}{l}0.3 \\
2.1 \\
0.4 \\
\text { n.a. } \\
0.9\end{array}$ \\
\hline $\begin{array}{r}\text { Affected } \\
\text { by War }\end{array}$ & $\begin{array}{l}\text { Croatia } \\
\text { FYR Macedonia } / \\
\text { Armenia } \\
\text { Georgia } \\
\text { Azerbaijan } \\
\text { Tajikistan } \\
\text { Averages }\end{array}$ & $\begin{array}{l}4.02 \\
3.92 \\
1.44 \\
1.32 \\
1.03 \\
0.95 \\
2.11\end{array}$ & $\begin{array}{l}0.0 \\
\text { n.a. } \\
1.0 \\
0.0 \\
0.0 \\
0.0 \\
0.2\end{array}$ & $\begin{array}{l}9.3 \\
\text { n.a. } \\
1.0 \\
0.0 \\
0.0 \\
0.0 \\
1.7\end{array}$ & $\begin{array}{l}15.5 \\
18.0 \\
3.5 \\
0.0 \\
0.1 \\
0.0 \\
6.2\end{array}$ & $\begin{array}{l}17.8 \\
19.0 \\
3.5 \\
5.4 \\
0.2 \\
0.3 \\
7.7\end{array}$ & $\begin{array}{l}17.5 \\
19.0 \\
6.2 \\
8.4 \\
0.7 \\
1.1 \\
8.8\end{array}$ & $\begin{array}{l}18.0 \\
19.0 \\
5.6 \\
\text { n.a. } \\
0.9 \\
1.7 \\
9.0\end{array}$ \\
\hline $\begin{array}{l}\text { East } \\
\text { Asia }\end{array}$ & $\begin{array}{l}\text { Viet Nam } \\
\text { China } \\
\text { Averages }\end{array}$ & $\begin{array}{l}3.42 \\
3.08 \\
3.25\end{array}$ & $\begin{array}{l}\mathrm{n} / \mathrm{a} \\
2.6 \\
\mathrm{n} / \mathrm{a}\end{array}$ & $\begin{array}{l}n / a \\
2.5 \\
n / a\end{array}$ & $\begin{array}{l}n / a \\
2.3 \\
n / a\end{array}$ & $\begin{array}{l}n / a \\
2.3 \\
n / a\end{array}$ & $\begin{array}{l}\mathrm{n} / \mathrm{a} \\
2.6 \\
\mathrm{n} / \mathrm{a}\end{array}$ & $\begin{array}{l}\mathrm{n} / \mathrm{a} \\
2.8 \\
\mathrm{n} / \mathrm{a}\end{array}$ \\
\hline
\end{tabular}

$\mathrm{CLI}=$ Cumulative Liberalization Index.

a) Annual average

Source: World Bank, IMF, Transition report, EBRD, 1995. 
TABLE 7a:

Sectoral Shifts at Current Prices, 1989-94

\begin{tabular}{|c|c|c|c|c|c|}
\hline \multirow[b]{2}{*}{ Group } & \multirow[b]{2}{*}{ Countries } & \multirow{2}{*}{$\begin{array}{c}\text { Cumul } \\
\text { Lib Index }\end{array}$} & \multicolumn{3}{|c|}{$\begin{array}{c}\text { Change in share } \\
\% \text { of GDP }\end{array}$} \\
\hline & & & Industry & Agriculture & Services \\
\hline \multirow[t]{2}{*}{$\begin{array}{l}\text { Advanced } \\
\text { Reformers }\end{array}$} & $\begin{array}{l}\text { Slovenia }{ }^{a} \\
\text { Poland } \\
\text { Hungary } \\
\text { Czech Republic } \underline{b} \text { / } \\
\text { Slovak Republic }\end{array}$ & $\begin{array}{l}4.16 \\
4.14 \\
4.11 \\
3.61 \\
3.53\end{array}$ & $\begin{array}{l}-5.8 \\
-14.6 \\
-4.6 \\
-8.7 \\
-22.5\end{array}$ & $\begin{array}{l}0.0 \\
-7.2 \\
-7.2 \\
-2.3 \\
-1.6\end{array}$ & $\begin{array}{l}5.8 \\
21.8 \\
11.8 \\
11.0 \\
24.1\end{array}$ \\
\hline & Averages & 3.91 & -11.2 & -3.7 & 14.9 \\
\hline \multirow[t]{2}{*}{$\begin{array}{r}\text { High } \\
\text { Intermediate } \\
\text { Reformers }\end{array}$} & $\begin{array}{l}\text { Bulgaria } \\
\text { Estonia } \underline{\underline{b} /} \\
\text { Lithuania } \underline{b} / \\
\text { Latvia } \underline{\text { }} / \\
\text { Romania } \\
\text { Albania } \\
\text { Mongolia }\end{array}$ & $\begin{array}{l}2.96 \\
2.93 \\
2.62 \\
2.39 \\
2.35 \\
2.30 \\
2.27\end{array}$ & $\begin{array}{l}-25.0 \\
-8.4 \\
-3.4 \\
-13.1 \\
-20.8 \\
-20.1 \\
13.5\end{array}$ & $\begin{array}{c}1.7 \\
-10.0 \\
-6.7 \\
-4.3 \\
5.2 \\
14.8 \\
4.0\end{array}$ & $\begin{array}{c}23.3 \\
18.4 \\
10.1 \\
17.4 \\
15.6 \\
5.3 \\
-17.5\end{array}$ \\
\hline & Averages & 2.55 & -11.0 & 0.7 & 10.4 \\
\hline \multirow[t]{2}{*}{$\begin{array}{r}\text { Low } \\
\text { Intermediate } \\
\text { Reformers }\end{array}$} & $\begin{array}{l}\text { Russia } \\
\text { Kyrgyz Republic } \\
\text { Moldova } \\
\text { Kazakhstan }\end{array}$ & $\begin{array}{l}1.90 \\
1.81 \\
1.62 \\
1.31\end{array}$ & $\begin{array}{l}-7.8 \\
-11.9 \\
-0.3 \\
12.3\end{array}$ & $\begin{array}{l}-10.3 \\
1.8 \\
7.5 \\
-18.5\end{array}$ & $\begin{array}{l}18.1 \\
10.1 \\
-7.2 \\
6.2\end{array}$ \\
\hline & Averages & 1.66 & -1.9 & -4.9 & 6.8 \\
\hline \multirow[t]{2}{*}{$\begin{array}{r}\text { Slow } \\
\text { Reformers }\end{array}$} & $\begin{array}{l}\text { Uzbekistan } \\
\text { Belarus } \underline{b} / \\
\text { Ukraine } \\
\text { Turkmenistan } \underline{b}\end{array}$ & $\begin{array}{l}1.11 \\
1.07 \\
0.80 \\
0.63\end{array}$ & $\begin{array}{c}-5.8 \\
6.2 \\
-12.2 \\
23.4\end{array}$ & $\begin{array}{l}-2.6 \\
-5.6 \\
17.1 \\
-14.6\end{array}$ & $\begin{array}{l}8.4 \\
-0.6 \\
-4.9 \\
-8.8\end{array}$ \\
\hline & Averages & 0.90 & 2.9 & -1.4 & -1.5 \\
\hline \multirow[t]{2}{*}{$\begin{array}{r}\text { Affected } \\
\text { by War }\end{array}$} & 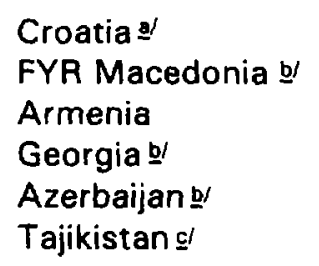 & $\begin{array}{l}4.02 \\
3.92 \\
1.44 \\
1.32 \\
1.03 \\
0.95\end{array}$ & $\begin{array}{c}2.1 \\
0.2 \\
-27.4 \\
-21.1 \\
-2.8 \\
1.5\end{array}$ & $\begin{array}{c}2.1 \\
4.2 \\
44.5 \\
36.6 \\
-1.6 \\
6.2\end{array}$ & $\begin{array}{l}-4.2 \\
-4.4 \\
-17.1 \\
-15.5 \\
4.4 \\
-7.7\end{array}$ \\
\hline & Averages & 2.11 & -7.9 & 15.3 & -7.4 \\
\hline \multirow[t]{2}{*}{$\begin{array}{l}\text { East } \\
\text { Asia }\end{array}$} & $\begin{array}{l}\text { Viet Nam } \\
\text { China }\end{array}$ & $\begin{array}{l}3.42 \\
3.08\end{array}$ & $\begin{array}{l}1.8 \\
4.2\end{array}$ & $\begin{array}{l}-12.8 \\
-8.7\end{array}$ & $\begin{array}{l}11.0 \\
4.5\end{array}$ \\
\hline & Averages & 3.25 & 3.0 & -10.8 & 7.8 \\
\hline
\end{tabular}

a/ Change over 1990-94.

b/ Change over 1989-93.

c/ Change over 1989-91.

Source: World Bank 
TABLE 7b:

Sectoral Shifts at Constant Prices, 1989-94

\begin{tabular}{|c|c|c|c|c|c|}
\hline \multirow[b]{2}{*}{ Group } & \multirow[b]{2}{*}{ Countries } & \multirow{2}{*}{$\begin{array}{l}\text { Cumul } \\
\text { Lib Index }\end{array}$} & \multicolumn{3}{|c|}{$\begin{array}{c}\text { Change in share } \\
\% \text { of GDP }\end{array}$} \\
\hline & & & Industry & Agriculture & Services \\
\hline \multirow[t]{2}{*}{$\begin{array}{l}\text { Advanced } \\
\text { Reformers }\end{array}$} & $\begin{array}{l}\text { Slovenias/ } \\
\text { Poland } \mathbf{y} \\
\text { Hungary } \\
\text { Czech Republic } \\
\text { Slovak Republic }\end{array}$ & $\begin{array}{l}4.16 \\
4.14 \\
4.11 \\
3.61 \\
3.53\end{array}$ & $\begin{array}{r}-23.3 \\
-21.4 \\
-0.2 \\
-10.5 \\
-14.8\end{array}$ & $\begin{array}{r}-3.8 \\
-2.0 \\
-1.7 \\
-0.5 \\
0.2\end{array}$ & $\begin{array}{r}27.1 \\
23.4 \\
1.9 \\
11.0 \\
14.6\end{array}$ \\
\hline & Averages & 3.91 & -14.0 & -1.6 & 15.6 \\
\hline \multirow[t]{2}{*}{ Reformers } & $\begin{array}{l}\text { Bulgaria } \\
\text { Estonia } \mathbf{a} / \\
\text { Lithuania } \mathbf{b} \text { / } \\
\text { Latvia } \mathbf{y} \\
\text { Romania } \\
\text { Albania } \\
\text { Mongolia }\end{array}$ & $\begin{array}{l}2.96 \\
2.93 \\
2.62 \\
2.39 \\
2.35 \\
2.30 \\
2.27\end{array}$ & $\begin{array}{r}-10.3 \\
-12.7 \\
-11.5 \\
-18.8 \\
-6.5 \\
-20.1 \\
3.0\end{array}$ & $\begin{array}{r}4.3 \\
-10.1 \\
2.6 \\
1.9 \\
6.2 \\
14.8 \\
4.3\end{array}$ & $\begin{array}{r}6.0 \\
22.8 \\
8.9 \\
16.9 \\
0.3 \\
5.3 \\
-7.3\end{array}$ \\
\hline & Averages & 2.55 & -11.0 & 3.4 & 7.6 \\
\hline \multirow[t]{2}{*}{ Reformers } & $\begin{array}{l}\text { Russia } \underline{\text { b }} \\
\text { Kyrgyz Republic } \\
\text { Moldova } \\
\text { Kazakhstan }\end{array}$ & $\begin{array}{l}1.90 \\
1.81 \\
1.62 \\
1.31\end{array}$ & $\begin{array}{r}3.5 \\
-7.8 \\
3.5 \\
-6.3\end{array}$ & $\begin{array}{r}6.5 \\
7.2 \\
6.5 \\
17.5\end{array}$ & $\begin{array}{r}-10.0 \\
0.6 \\
-10.0 \\
-11.2\end{array}$ \\
\hline & Averages & 1.67 & -1.8 & 9.4 & -7.7 \\
\hline \multirow[t]{2}{*}{$\begin{array}{r}\text { Slow } \\
\text { Reformers }\end{array}$} & $\begin{array}{l}\text { Uzbekistan } \mathbf{g} \\
\text { Belarus } \mathbf{g} \\
\text { Ukraine } \\
\text { Turkmenistan } !\end{array}$ & $\begin{array}{l}1.11 \\
1.07 \\
0.80 \\
0.63\end{array}$ & $\begin{array}{r}-7.6 \\
5.8 \\
-11.2 \\
-4.5\end{array}$ & $\begin{array}{r}12.7 \\
-2.8 \\
10.0 \\
0.1\end{array}$ & $\begin{array}{r}-5.1 \\
-3.0 \\
1.2 \\
4.4\end{array}$ \\
\hline & Averages & 0.90 & -4.4 & 5.0 & -0.6 \\
\hline $\begin{array}{l}\text { Affected } \\
\text { by War }\end{array}$ & $\begin{array}{l}\text { Croatia } \\
\text { FYR Macedonia } \\
\text { Armenias }{ }^{\prime} \\
\text { Georgia } \\
\text { Azerbaijan } \\
\text { Tajikistan } \\
\text { Averages } \\
\end{array}$ & $\begin{array}{l}4.02 \\
3.92 \\
1.44 \\
1.32 \\
1.03 \\
0.95 \\
2.11 \\
\end{array}$ & $\begin{array}{r}-4.0 \\
9.1 \\
-6.4 \\
-8.7 \\
-14.8 \\
\text { n.a. } \\
-5.0 \\
\end{array}$ & $\begin{array}{r}0.8 \\
-6.0 \\
0.0 \\
18.3 \\
0.2 \\
\text { n.a. } \\
2.7 \\
\end{array}$ & $\begin{array}{r}3.2 \\
-3.1 \\
6.4 \\
-9.6 \\
14.6 \\
\text { n.a. } \\
2.3 \\
\end{array}$ \\
\hline \multirow[t]{2}{*}{$\begin{array}{l}\text { East } \\
\text { Asia }\end{array}$} & $\begin{array}{l}\text { Viet Nam } \\
\text { China }\end{array}$ & $\begin{array}{l}3.42 \\
3.08\end{array}$ & $\begin{array}{r}-1.1 \\
18.6\end{array}$ & $\begin{array}{l}-6.0 \\
-6.1\end{array}$ & $\begin{array}{r}7.1 \\
-12.5\end{array}$ \\
\hline & Averages & 3.25 & 8.8 & -6.1 & -2.7 \\
\hline
\end{tabular}
a/ Change over 1989-93
b/ Change over 1989-92
c/ Change over 1989-91 
TABLE 8:

Levels and Change in Revenue, Expenditures and Fiscal Balance, 1989-94

\begin{tabular}{|c|c|c|c|c|c|c|c|c|}
\hline \multirow[b]{2}{*}{ Group } & \multirow[b]{2}{*}{ Countries } & \multirow{2}{*}{$\begin{array}{c}\text { Cumul } \\
\text { Lib Index } \\
\end{array}$} & \multicolumn{3}{|c|}{$\begin{array}{l}\text { Change in } \\
(\% \text { of GDP) }\end{array}$} & \multicolumn{3}{|c|}{$\begin{array}{l}\text { Levels, } 1994 \\
\text { (\% of GDP) }\end{array}$} \\
\hline & & & Revenue & Expenditure & Balance & Revenue & Expenditure & Balance \\
\hline Advanced & Slovenia & 4.16 & 4.6 & 5.8 & -1.2 & 46.6 & 47.5 & -0.9 \\
\hline \multirow[t]{5}{*}{ Reformers } & Poland & 4.14 & 6.5 & 1.5 & 5.0 & 47.9 & 50.4 & -2.5 \\
\hline & Hungary & 4.11 & -6.8 & -1.7 & -5.1 & 52.3 & 58.8 & -6.5 \\
\hline & Czech Republic $\mathbf{a}^{\prime}$ & 3.61 & -10.9 & -13.8 & 2.9 & 51.2 & 50.7 & 0.5 \\
\hline & Slovak Republic $\mathbf{a}^{\prime}$ & 3.53 & -11.6 & -11.5 & -0.1 & 50.5 & 53.0 & -2.5 \\
\hline & Averages & 3.91 & -3.6 & -3.9 & 0.3 & 49.7 & 52.1 & -2.4 \\
\hline High & Bulgaria & 2.96 & -21.9 & -17.3 & -4.6 & 38.0 & 44.1 & -6.1 \\
\hline Intermediate & Estonia & 2.93 & -8.0 & -7.5 & -0.5 & 35.0 & 35.0 & 0.0 \\
\hline \multirow[t]{6}{*}{ Reformers } & Lithuania & 2.62 & -25.2 & -17.1 & -8.1 & 25.1 & 30.4 & -5.3 \\
\hline & Latvia & 2.39 & -15.1 & -12.3 & -2.8 & 36.7 & 38.7 & -2.0 \\
\hline & Romania & 2.35 & -18.5 & -7.1 & -11.4 & 32.6 & 35.6 & -3.0 \\
\hline & Albania & 2.30 & -20.3 & -16.0 & -4.3 & 27.7 & 41.0 & -13.3 \\
\hline & Mongolia & 2.27 & -12.4 & -17.3 & 5.0 & 36.2 & 48.0 & -11.8 \\
\hline & Averages & 2.55 & -17.3 & -13.5 & -3.8 & 33.0 & 39.0 & -5.9 \\
\hline Low & Russia & 1.90 & -4.5 & -4.4 & -0.1 & 36.3 & 45.1 & -8.8 \\
\hline Intermediate & Kyrgyz Republic & 1.81 & -14.2 & -3.7 & -10.4 & 24.3 & 32.7 & -8.4 \\
\hline \multirow[t]{3}{*}{ Reformers } & Moldova & 1.62 & -18.2 & -7.8 & -7.1 & 17.1 & 25.9 & -8.8 \\
\hline & Kazakhstan & 1.31 & -21.7 & -15.7 & -6.0 & 19.0 & 23.5 & -4.5 \\
\hline & Averages & 1.66 & -14.6 & -7.9 & -5.9 & 24.2 & 31.8 & -7.6 \\
\hline Slow & Uzbekistan & 1.11 & 7.8 & 9.2 & -1.4 & 43.0 & 45.0 & -2.0 \\
\hline \multirow[t]{4}{*}{ Reformers } & Belarus & 1.07 & -1.6 & 3.4 & -1.5 & 36.6 & 38.1 & -1.5 \\
\hline & Ukraine & 0.80 & 15.9 & 25.7 & -8.4 & 42.3 & 51.4 & -9.1 \\
\hline & Turkmenistan & 0.63 & -26.2 & -23.9 & -2.3 & 6.2 & 7.3 & -1.1 \\
\hline & Averages & 0.90 & -1.0 & 3.6 & -3.4 & 32.0 & 35.5 & -3.4 \\
\hline Affected & Croatia $\mathrm{b} f$ & 4.02 & 12.3 & 8.1 & 4.1 & 27.2 & 27.6 & -0.4 \\
\hline \multirow[t]{6}{*}{ by War } & FYR Macedonia & 3.92 & 6.6 & 5.6 & 1.1 & 42.8 & 45.4 & -2.6 \\
\hline & Armenia & 1.44 & -15.2 & 11.2 & -21.6 & 37.0 & 61.0 & -24.0 \\
\hline & Georgia & 1.32 & -16.5 & -6.6 & -8.1 & 15.0 & 24.0 & -9.0 \\
\hline & Azerbaijan & 1.03 & 10.2 & 24.7 & -11.5 & 36.0 & 49.0 & -13.0 \\
\hline & Tajikistan & 0.95 & -4.9 & -0.5 & -1.0 & 35.4 & 38.1 & -2.7 \\
\hline & Averages & 2.11 & -1.2 & 7.1 & -6.2 & 32.2 & 40.9 & -8.6 \\
\hline East & Viet Nam & 3.42 & 8.7 & -3.2 & 5.5 & 24.7 & 25.2 & -0.5 \\
\hline \multirow[t]{2}{*}{ Asia } & China & 3.08 & -5.1 & -4.7 & -0.4 & 11.4 & 13.3 & -1.9 \\
\hline & Averages & 3.25 & 1.8 & -2.2 & 2.5 & 18.1 & 19.3 & -1.2 \\
\hline
\end{tabular}

a) 1989 figures for Czechoslovakia.

b/ Change over 1991-94

Source: IMF, World Bank 
TABLE 9:

Fiscal Deficits and Quasi-Fiscal Expenditures for Selected Countries, 1992-94 (as percentage of GDP)

\begin{tabular}{|c|c|c|c|c|c|c|c|c|c|}
\hline & \multicolumn{3}{|c|}{ Fiscal Deficits } & \multicolumn{3}{|c|}{ CB Implicit Subsidy ${ }^{a)}$} & \multicolumn{3}{|c|}{ Total } \\
\hline & 1992 & 1993 & 1994 & 1992 & 1993 & 1994 & 1992 & 1993 & 1994 \\
\hline \multicolumn{10}{|l|}{ Advanced Reformers } \\
\hline Poland & 6.8 & 2.9 & 2.9 & 0.0 & 0.0 & 0.0 & 6.8 & 2.9 & 2.9 \\
\hline Hungary & 5.7 & 7.0 & 6.5 & 0.0 & 0.0 & 0.0 & 5.7 & 7.0 & 6.5 \\
\hline Czech Republic b) & 0.5 & -0.6 & -0.5 & 0.3 & 0.8 & 0.1 & 0.8 & 0.2 & -0.4 \\
\hline Slovakia bl & 13.1 & 7.6 & 2.5 & 0.3 & 1.7 & 0.0 & 13.4 & 9.3 & 2.5 \\
\hline \multicolumn{10}{|l|}{ Intermediate Roformers } \\
\hline Bulgaria & 5.0 & 11.1 & 6.1 & 1.3 & 0.8 & 0.7 & 6.3 & 11.9 & 6.8 \\
\hline Estonia cl & -0.5 & 1.4 & 0.0 & - & 0.2 & 0.3 & - & 1.6 & 0.3 \\
\hline Romania & 5.5 & 1.0 & 3.0 & 5.9 & 3.9 & 0.0 & 11.4 & 4.9 & 3.0 \\
\hline Russiac) & 3.4 & 8.1 & 8.8 & 11.3 & 1.7 & 0.0 & 14.7 & 9.8 & 8.8 \\
\hline Kazakhstan & 7.3 & 1.2 & 4.5 & 32.7 & & 2.6 & 40.0 & & 7.1 \\
\hline \multicolumn{10}{|l|}{ Slow Reformers } \\
\hline Belarus c) & 6.4 & 9.4 & 1.5 & 26.5 & 9.3 & 3.4 & 32.9 & 18.7 & 4.9 \\
\hline Turkmenistan cl & 10.1 & 3.6 & 1.1 & 12.5 & 21.2 & 6.4 & 22.6 & 24.8 & 7.5 \\
\hline Uzbekistancl & 10.2 & 8.4 & 2.0 & 13.1 & 18.5 & 19.0 & 23.3 & 26.9 & 21.0 \\
\hline
\end{tabular}

a) Implicit subsidy from the Central Bank to commercial banks and economy due to difference between the Central Bank refinancing rate and inflation. Annual figures are averages of monthly (quarterly) figures

b) For 1992 the nominal federation subsidy is divided 2 to 1 in favor of the Czech Republic.

c) Calculations done on quarterly basis. 
TABLE 10:

Money, Interest Rates and Real Balances

\begin{tabular}{|c|c|c|c|c|c|c|c|c|}
\hline \multirow[t]{2}{*}{ Group } & \multirow[t]{2}{*}{ Countries } & \multirow[t]{2}{*}{$\begin{array}{l}\text { Cumul } \\
\text { Lib Index }\end{array}$} & \multirow[t]{2}{*}{$\begin{array}{c}\text { Broad Money } \\
\text { Growth } \\
\text { (Average Monthly } \\
\text { Change 1992-94) }\end{array}$} & \multicolumn{3}{|c|}{$\begin{array}{c}\text { Real Money Balances } \\
1991=100 \\
\end{array}$} & \multicolumn{2}{|c|}{$\begin{array}{l}\text { Discount Rate in Real } \\
\text { Terms, percent (average) }\end{array}$} \\
\hline & & & & 92 & 93 & 94 & $1992-1994$ & end-1994 \\
\hline Advanced & Slovenia & 4.16 & 5 & 92 & 127 & 164 & -3 & -1 \\
\hline \multirow[t]{5}{*}{ Reformers } & Poland & 4.14 & 3 & 98 & 101 & 104 & 1 & 3 \\
\hline & Hungary & 4.11 & 2 & 105 & 106 & 102 & 0 & 1 \\
\hline & Czech Republic a & 3.61 & 1 & 106 & 104 & 111 & -1 & -1 \\
\hline & Slovak Republic al & 3.53 & 1 & 95 & 84 & 86 & -1 & -1 \\
\hline & Averages & 3.91 & 2 & 99 & 104 & 113 & -1 & 0 \\
\hline High & Bulgaria & 2.96 & 4 & 91 & 76 & 68 & -3 & 0 \\
\hline Intermediate & Estonia !! & 2.93 & 7 & 25 & 20 & 21 & $\mathrm{n} / \mathrm{a}$ & -3 \\
\hline \multirow[t]{6}{*}{ Reformers } & Lithuania & 2.62 & 9 & 30 & 17 & 20 & $\mathrm{n} / \mathrm{a}$ & $n / a$ \\
\hline & Latvia & 2.39 & 6 & 29 & 28 & 34 & -8 & 0 \\
\hline & Romania $\underline{e}^{\prime}$ & 2.35 & 7 & 63 & 43 & 41 & -8 & 12 \\
\hline & Albania & 2.30 & $5 \underline{y}$ & 82 & 89 & 105 & -4 & 2 \\
\hline & Mongolia ${ }^{9 \prime}$ & 2.27 & $6 \underline{b}$ & 56 & 36 & 40 & -16 & -8 \\
\hline & Averages & 2.55 & 6 & 54 & 44 & 47 & -8 & 1 \\
\hline Low & Russia & 1.92 & 15 & 32 & 23 & 16 & -17 & -2 \\
\hline Intermediate & Kyrgyz Republic & 1.81 & 11 & 36 & 16 & 8 & -19 & 9 \\
\hline \multirow{3}{*}{ Reformers } & Moldova & 1.62 & 13 & 23 & 9 & 3 & -18 & 0 \\
\hline & Kazakhstan & 1.31 & 19 & 21 & 14 & 8 & -31 & 4 \\
\hline & Averages & 1.67 & 15 & 28 & 16 & 9 & -21 & 3 \\
\hline Slow & Uzbekistan & 1.11 & 19 & 45 & 53 & 71 & -35 & -12 \\
\hline \multirow[t]{4}{*}{ Reformers } & Belarus & 1.07 & 20 & 35 & 33 & 17 & -34 & -5 \\
\hline & Ukraine & 0.80 & 22 & 40 & 26 & 13 & -29 & -40 \\
\hline & Turkmenistan & 0.63 & 23 & 63 & 73 & 9 & -45 & -48 \\
\hline & Averages & 0.90 & 21 & 46 & 46 & 28 & -36 & -26 \\
\hline \multirow{7}{*}{$\begin{array}{r}\text { Affected } \\
\text { by War }\end{array}$} & Croatia ${ }^{\prime}$ & 4.02 & 16 & 68 & 60 & 76 & -9 & 2 \\
\hline & FYR Macedonia & 3.92 & $19 \mathrm{c}^{l}$ & 89 & 91 & 89 & -1 & 1 \\
\hline & Armenia & 1.44 & 24 & 22 & 7 & 2 & -33 & -26 \\
\hline & Georgia & 1.32 & 29 & 29 & 24 & 6 & $\mathrm{n} / \mathrm{a}$ & $n / a$ \\
\hline & Azerbaijan & 1.03 & 17 & 40 & 40 & 19 & -40 & -52 \\
\hline & Tajikistan & 0.95 & 19 & 39 & 30 & $\mathrm{n} / \mathrm{a}$ & -30 & -16 \\
\hline & Averages & 2.11 & 21 & 48 & 42 & 39 & -23 & -18 \\
\hline East & Viet $\mathrm{Nam} \stackrel{\mathrm{c}}{ }$ & 3.42 & $\mathrm{n} / \mathrm{a}$ & 97 & 107 & $\mathrm{n} / \mathrm{a}$ & 1 & 0.6 \\
\hline \multirow[t]{2}{*}{ Asia } & China & 3.08 & $2^{\prime \prime}$ & 123 & 141 & 168 & -5 & -5 \\
\hline & Averages & 3.25 & $\mathrm{n} / \mathrm{a}$ & 110 & 124 & $n / a$ & -2 & -2.2 \\
\hline
\end{tabular}

NB: The discount rates in real terms are calculated assuming quarterly compounding. All averages are simple averages

a/ Data for 1992 are for the federation.

b/ Broad money growth rate is taken from a quarterly average made monthly by taking a cubic root.

$\mathrm{c} /$ The average discount rate is for 1992-93. For Vietnam, the lending rate for working capital is used.

d/ The rates for 1992-93 are decompounded on monthly basis.

e/ Average interest rate collected over different types of credit.

$f /$ The NBE credit auction rate is used for end 1994.

$\mathrm{g}$ / The discount rate used is the clearing and settlement account; a mid point of range is used. 
TABLE 11:

Political Freedom and Degree of Liberalization

\begin{tabular}{|c|c|c|c|}
\hline Group & Countries & $\begin{array}{l}\text { Political } \\
\text { Freedom }\end{array}$ & $\begin{array}{c}\text { CLI } \\
1994 \\
\end{array}$ \\
\hline $\begin{array}{l}\text { Advanced } \\
\text { Reformers }\end{array}$ & $\begin{array}{l}\text { Slovenia } \\
\text { Poland } \\
\text { Hungary } \\
\text { Czech Rep } \\
\text { Slovakia } \\
\text { Averages }\end{array}$ & $\begin{array}{l}6.50 \\
6.00 \\
6.50 \\
6.50 \\
5.50 \\
6.20\end{array}$ & $\begin{array}{l}4.16 \\
4.14 \\
4.11 \\
3.61 \\
3.53 \\
3.91 \\
\end{array}$ \\
\hline $\begin{array}{r}\text { High } \\
\text { Intermediate } \\
\text { Reformers }\end{array}$ & $\begin{array}{l}\text { Bulgaria } \\
\text { Estonia } \\
\text { Lithuania } \\
\text { Latvia } \\
\text { Romania } \\
\text { Albania } \\
\text { Mongolia } \\
\text { Averages }\end{array}$ & $\begin{array}{l}6.00 \\
5.50 \\
6.00 \\
5.50 \\
4.50 \\
4.50 \\
5.50 \\
5.36\end{array}$ & $\begin{array}{l}2.96 \\
2.93 \\
2.62 \\
2.39 \\
2.35 \\
2.30 \\
2.27 \\
2.55\end{array}$ \\
\hline $\begin{array}{r}\text { Low } \\
\text { Intermediate } \\
\text { Reformers }\end{array}$ & $\begin{array}{l}\text { Russia } \\
\text { Kyrgyzstan } \\
\text { Moldova } \\
\text { Kazakhstan } \\
\text { Averages } \\
\end{array}$ & $\begin{array}{l}4.50 \\
4.50 \\
4.00 \\
2.50 \\
3.88 \\
\end{array}$ & $\begin{array}{l}1.92 \\
1.81 \\
1.62 \\
1.31 \\
1.67 \\
\end{array}$ \\
\hline $\begin{array}{r}\text { Slow } \\
\text { Reformers }\end{array}$ & $\begin{array}{l}\text { Uzbekistan } \\
\text { Belarus } \\
\text { Ukraine } \\
\text { Turkmenistan } \\
\text { Averages }\end{array}$ & $\begin{array}{l}1.00 \\
4.00 \\
4.50 \\
1.00 \\
2.63 \\
\end{array}$ & $\begin{array}{l}1.11 \\
1.07 \\
0.80 \\
0.63 \\
0.90\end{array}$ \\
\hline $\begin{array}{l}\text { Affected } \\
\text { by War }\end{array}$ & $\begin{array}{l}\text { Croatia } \\
\text { FYR Macedonia } \\
\text { Armenia } \\
\text { Georgia } \\
\text { Azerbaijan } \\
\text { Tajikistan } \\
\text { Averages } \\
\end{array}$ & $\begin{array}{l}4.00 \\
4.50 \\
4.50 \\
3.00 \\
2.00 \\
1.00 \\
3.17 \\
\end{array}$ & $\begin{array}{l}4.02 \\
3.92 \\
1.44 \\
1.32 \\
1.03 \\
0.95 \\
2.11 \\
\end{array}$ \\
\hline $\begin{array}{l}\text { East } \\
\text { Asia }\end{array}$ & $\begin{array}{l}\text { Viet Nam } \\
\text { China } \\
\text { Averages }\end{array}$ & $\begin{array}{l}1.00 \\
1.00 \\
1.00\end{array}$ & $\begin{array}{l}3.42 \\
3.08 \\
3.25\end{array}$ \\
\hline
\end{tabular}

Source: See Appendix for CLI (Cumulative Liberalization Index).

See Karatnycky (1995) for index of political freedom, which has been reversed for ease of comparison. 
Figure 1a:

Means of Liberalization Components

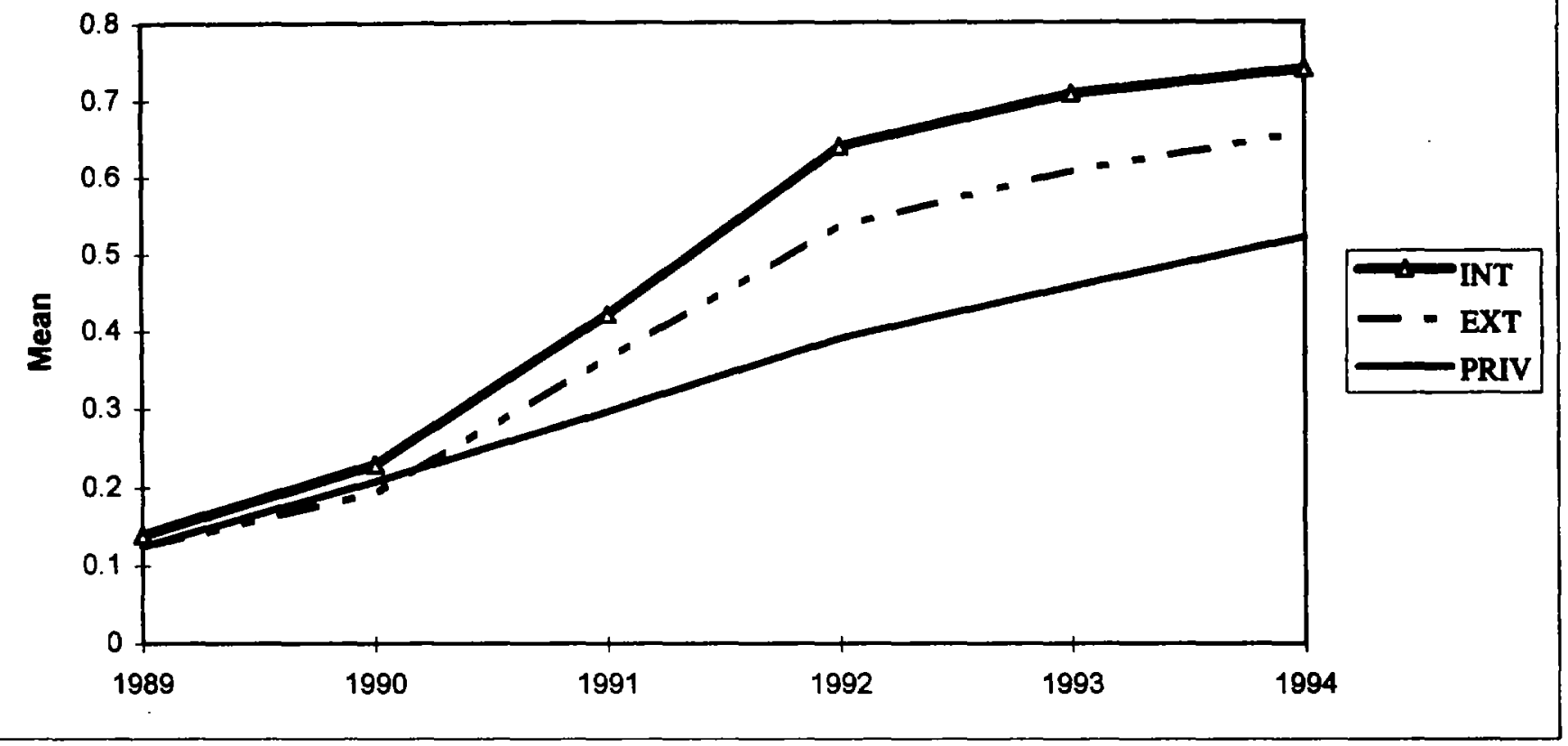

Figure 1b:

Standard Deviations of Liberalization Components

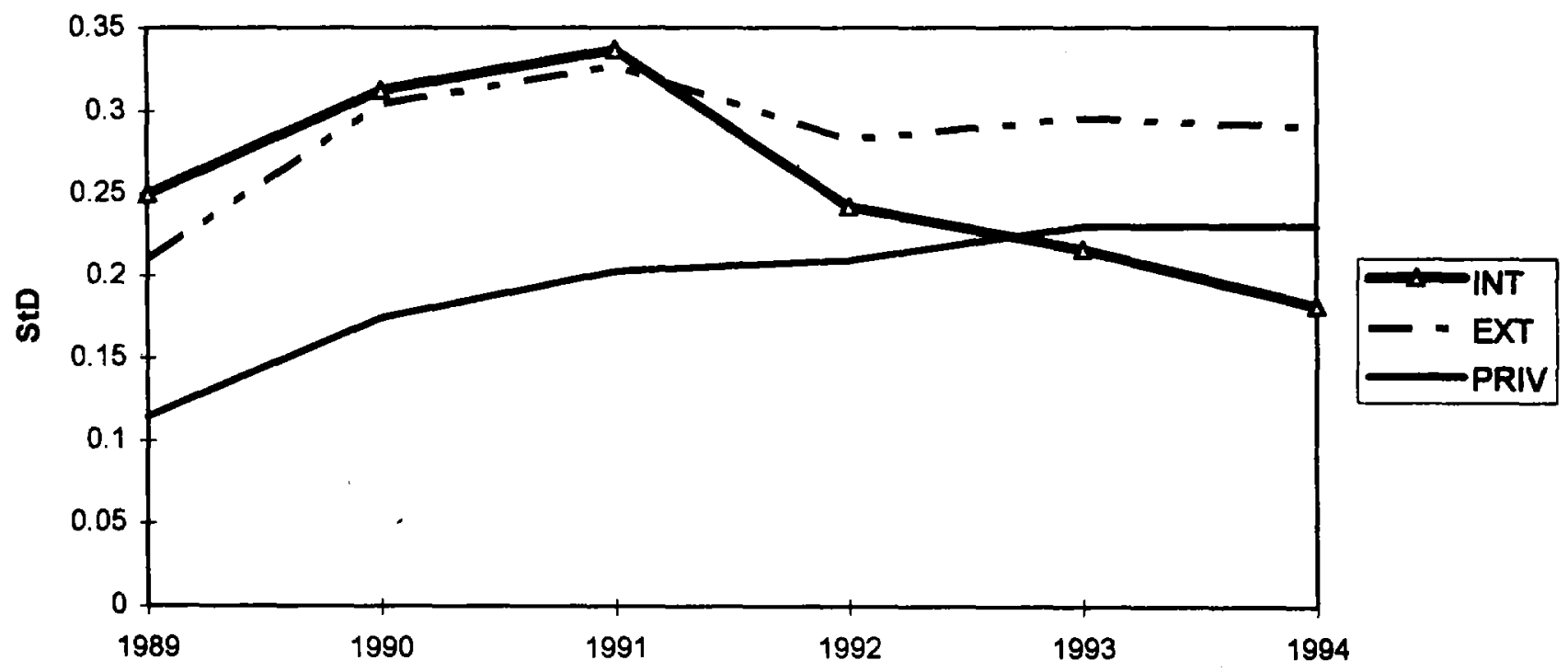

Source : See Appendix 
Figure 2: Growth and Liberalization

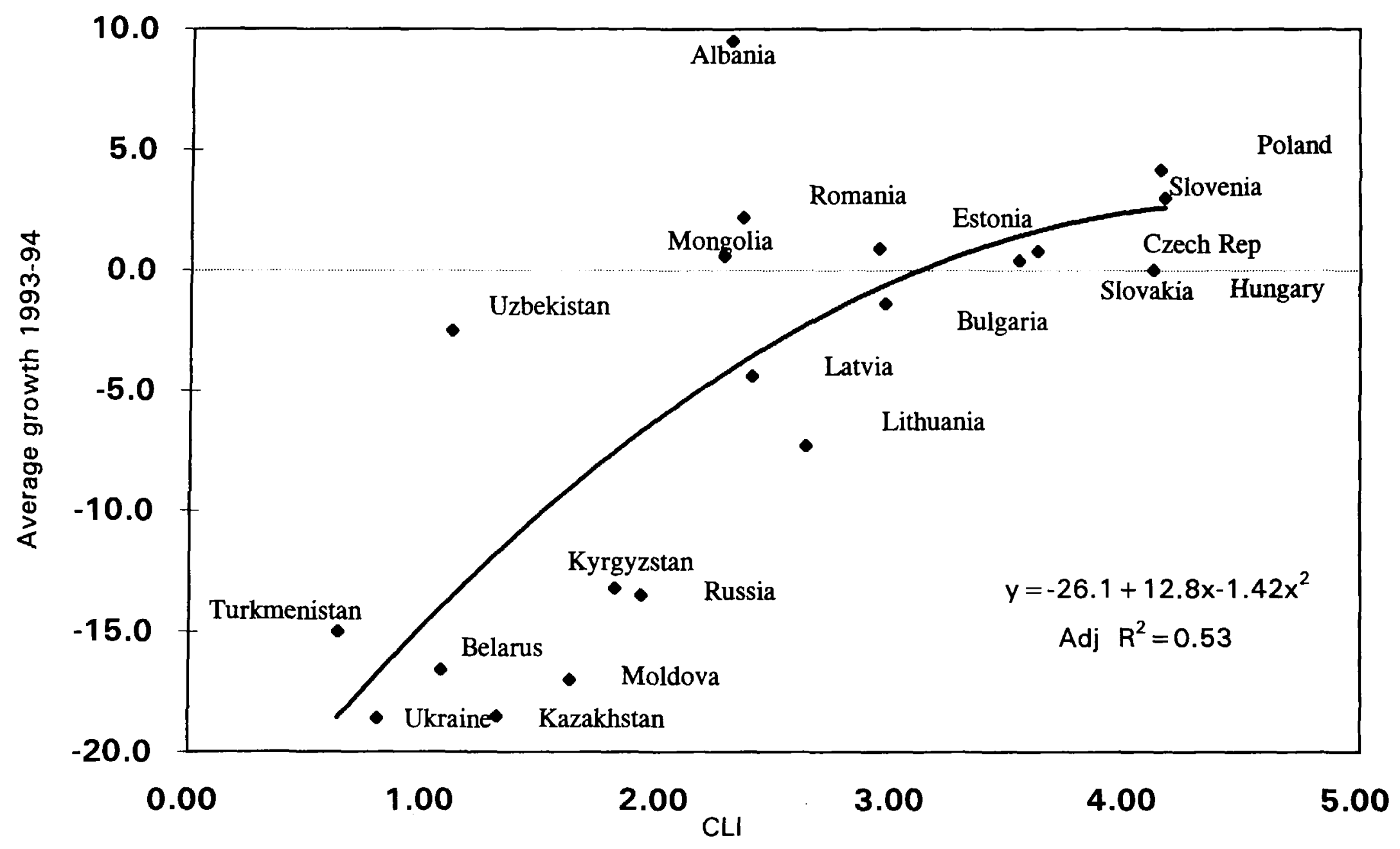


Figure 3: Inflation and Liberalization

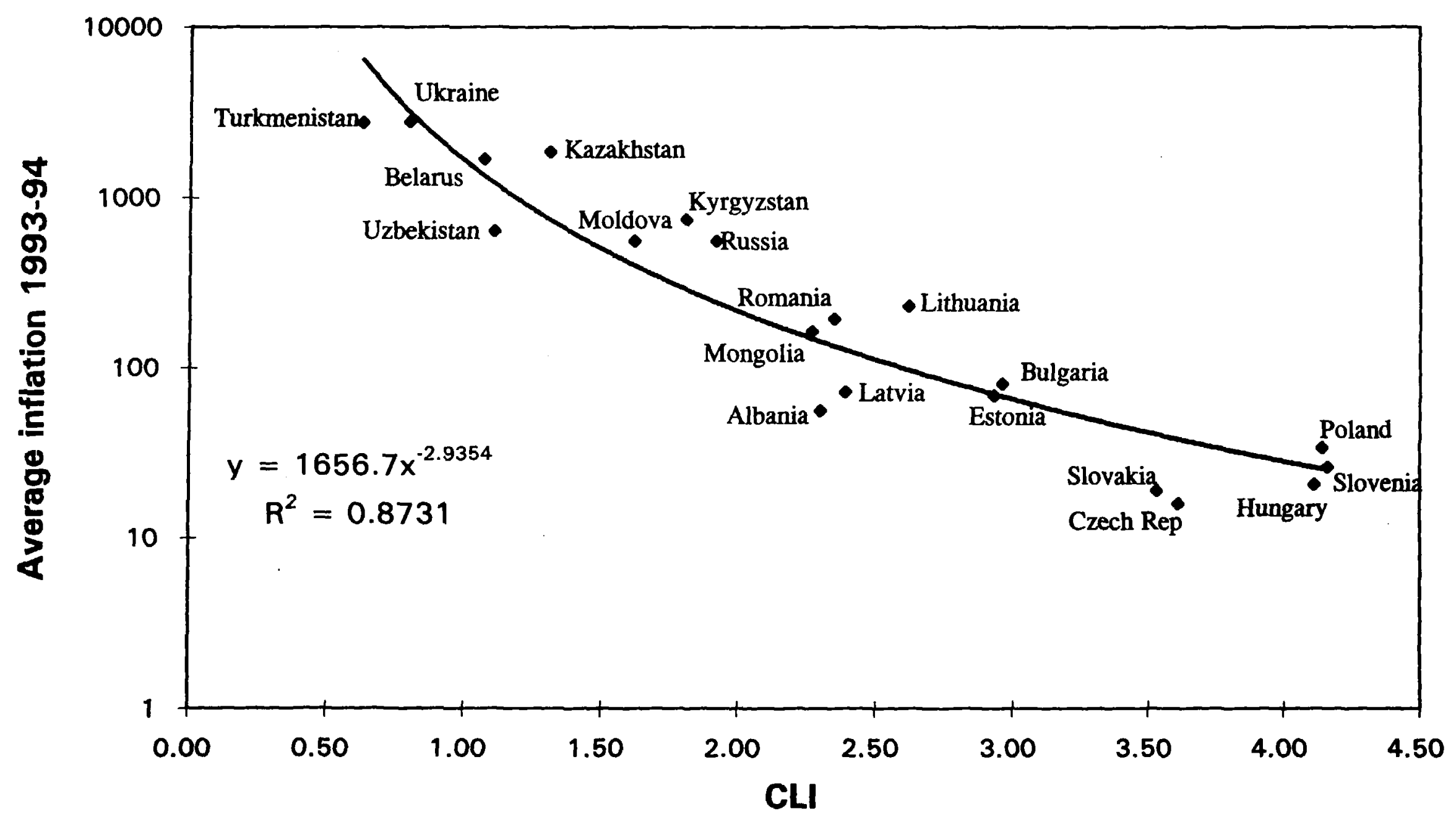


Figure 4: Growth and Stabilization ${ }^{\text {/a/ }}$

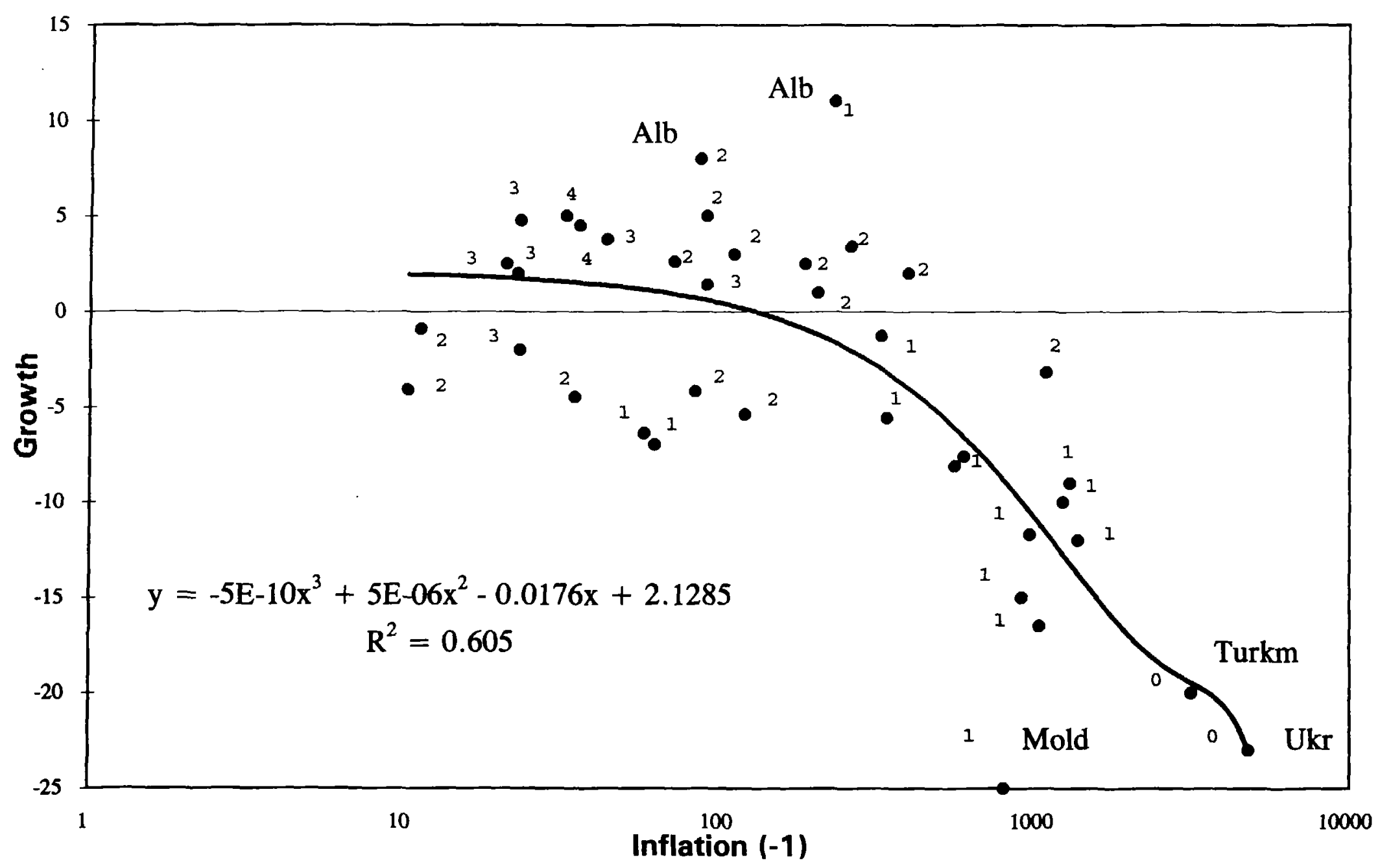




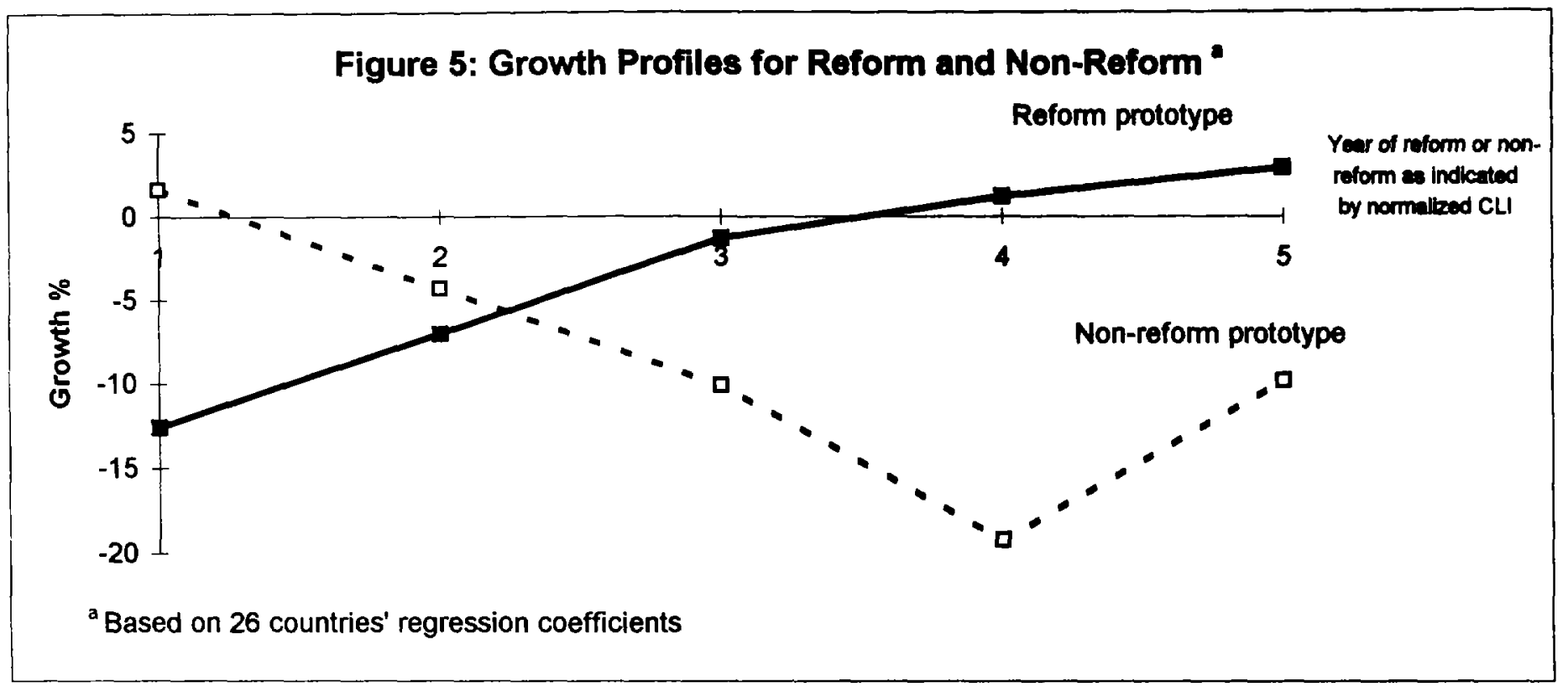

Figure 6: Inflation Profiles for Reform and Non-Reform *

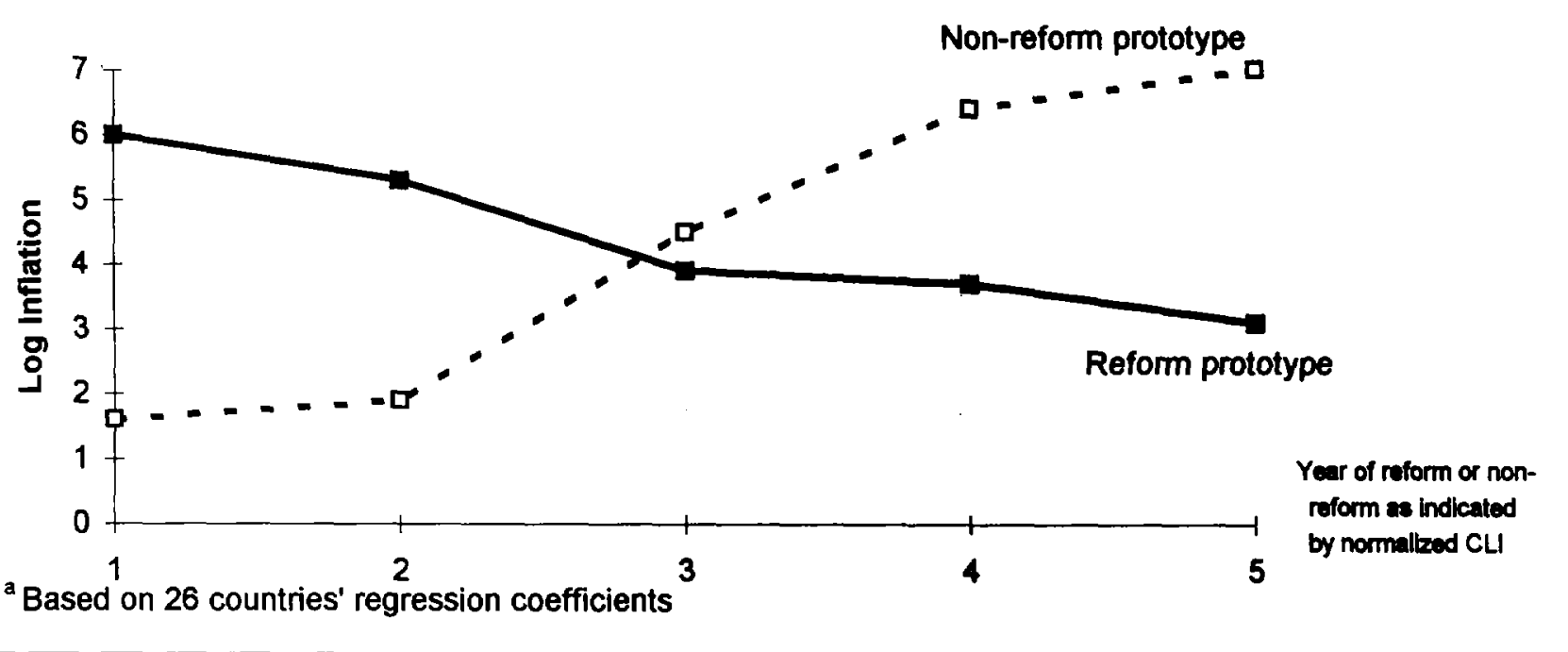


Figure 7: Paths of Growth by Reform Group

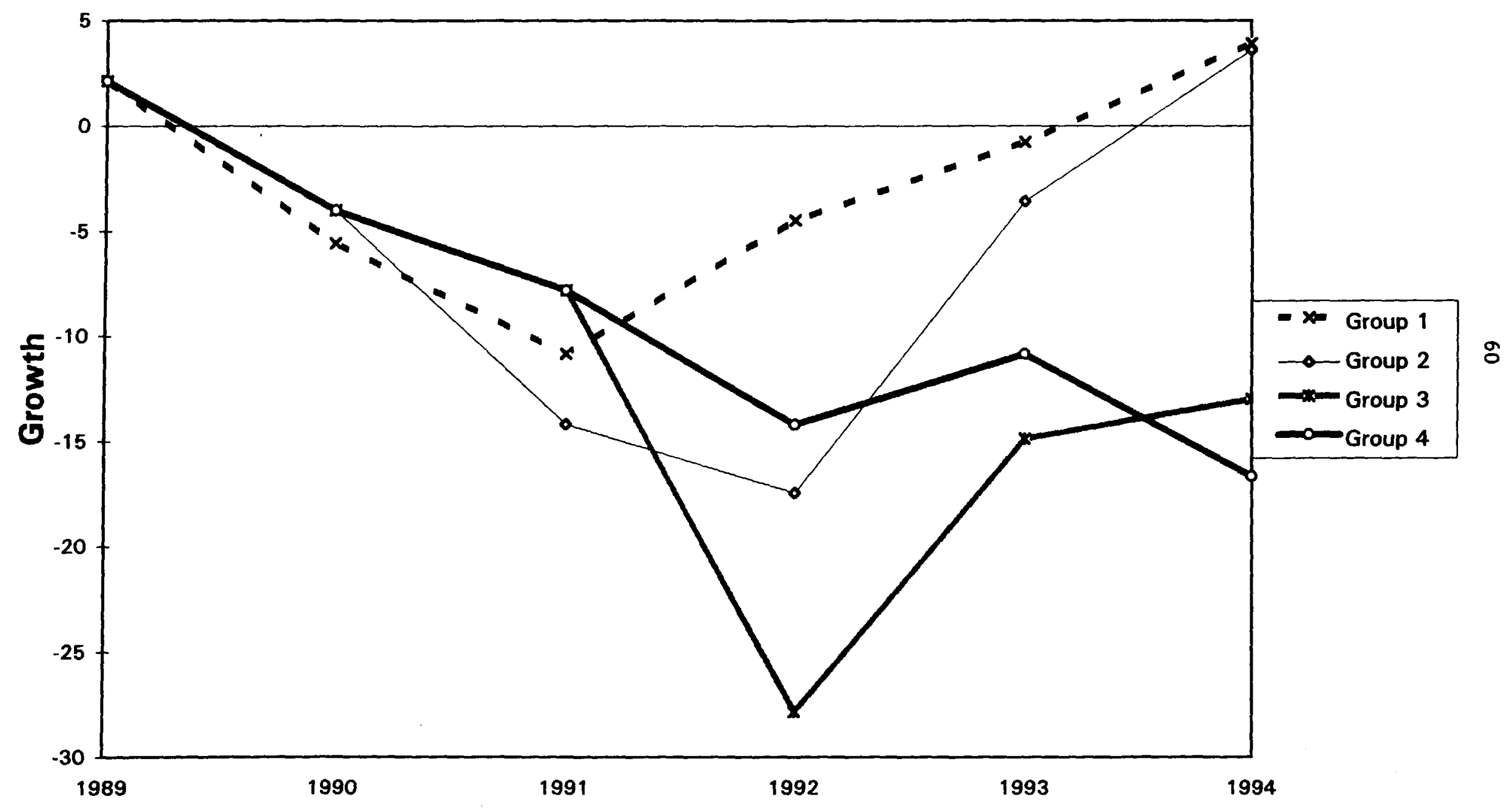


Figure 8: Inflation by Reform Group, 1989-1994

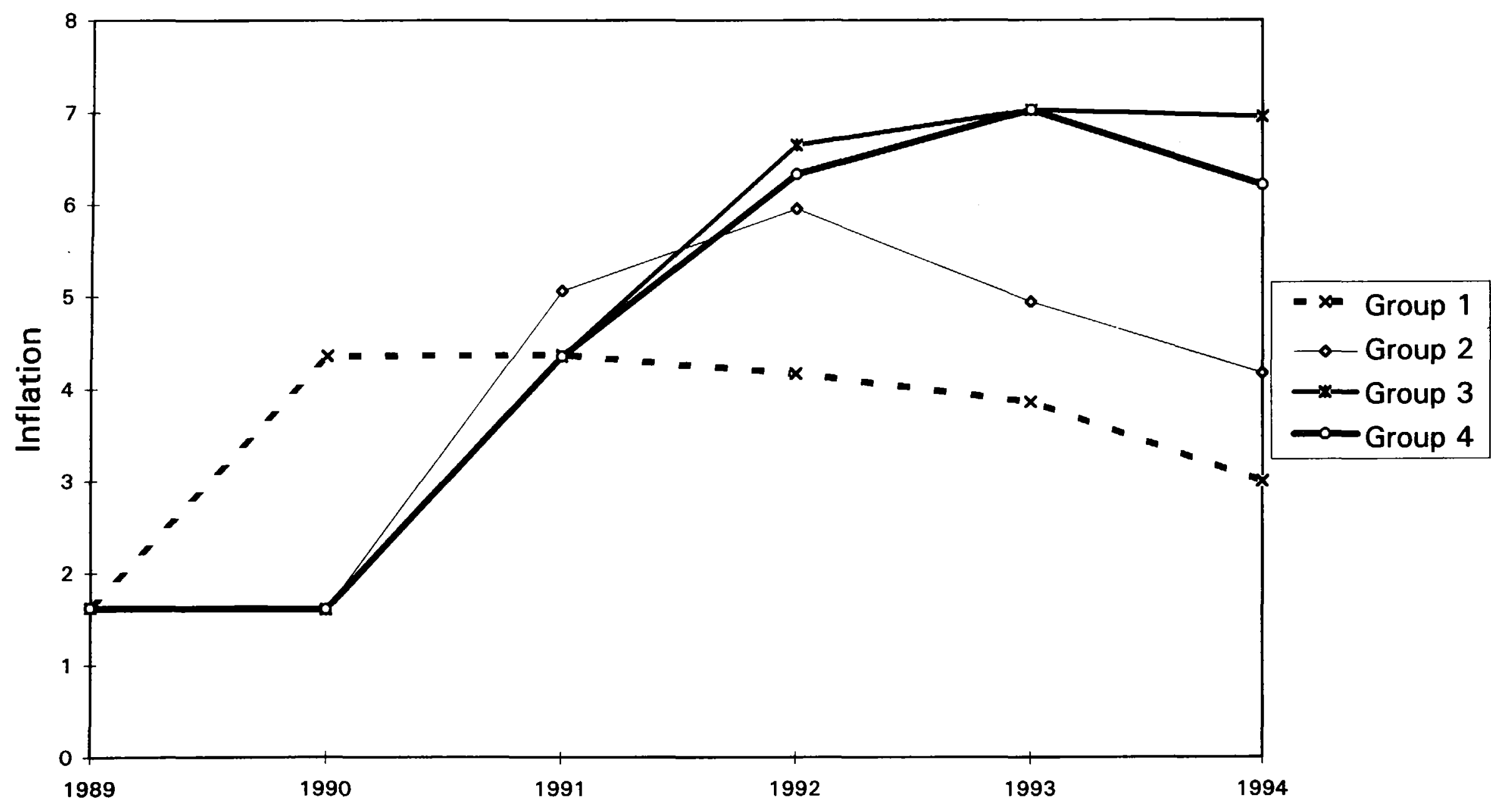



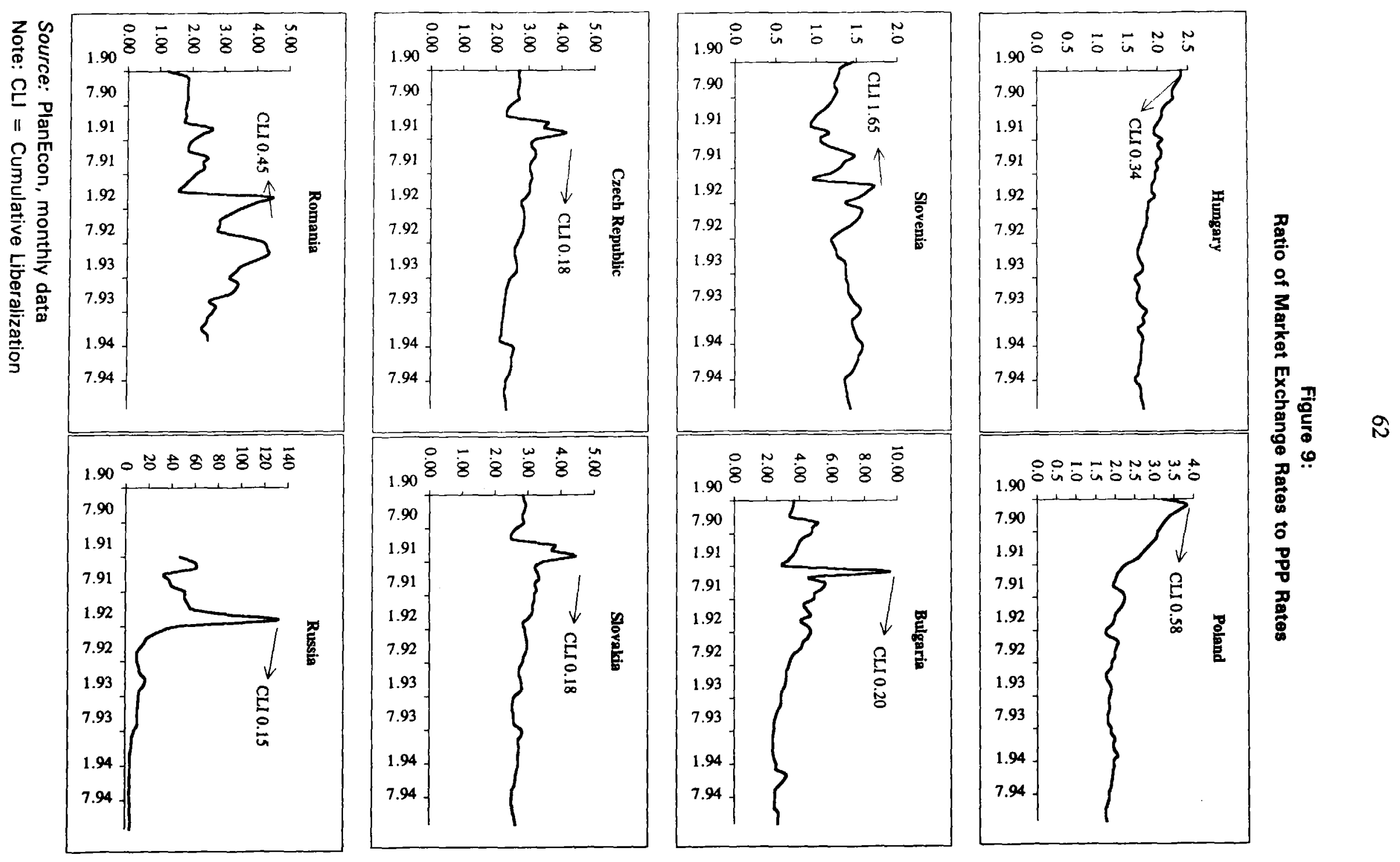
Figure 10: Political Freedom and Degree of Economic Liberalization

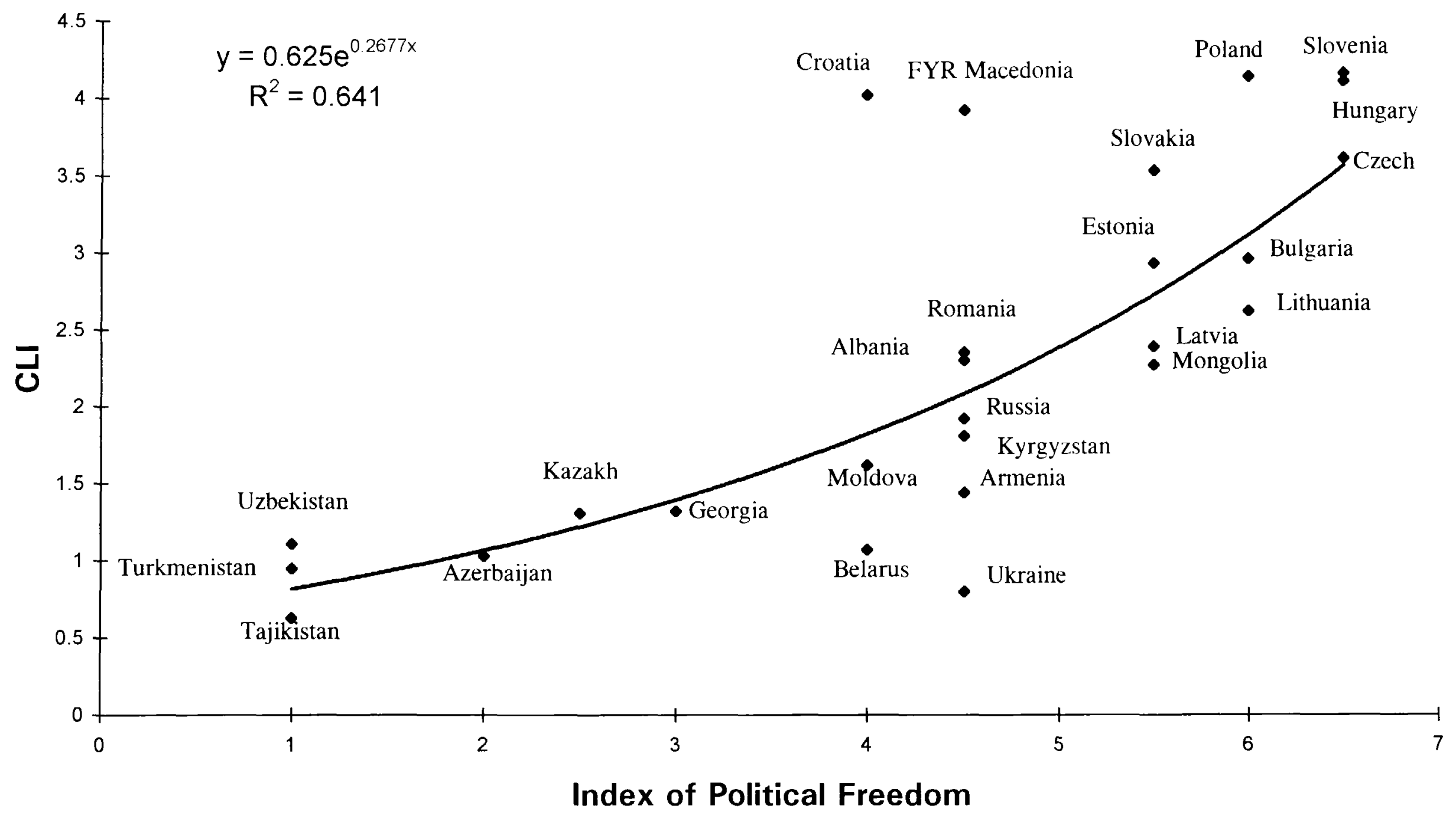

Source: Freedom Review, Jan 1995, Authors Notes: CLI-Cumulative Index of Liberalization;

Index of Political Freedom has been reversed for easier comparison with the CLI;

China and Vietnam excluded. 



\section{Policy Research Working Paper Series}

Title
WPS1545 International Commodity Control Retrospect and Prospect
WPS1546 Concessions of Busways to the Private Sector: The São Paulo Metropolitan Region Experience
WPS1547 Testing the Induced Innovation Hypothesis in South African Agriculture (An Error Correction Approach

WPS1548 The Relationship Between Farm Size and Efficiency in South African Agriculture

WPS1549 The Forgotten Rationale for Policy Reform: The Productivity of Investment Projects

WPS1550 Governance and Returns on Investment: An Empirical Investigation

WPS1551 Sequencing Social Security, Pension, and Insurance Reform

WPS1552 Unemployment insurance and Duration of Unemployment: Evidence from Slovenia's Transition

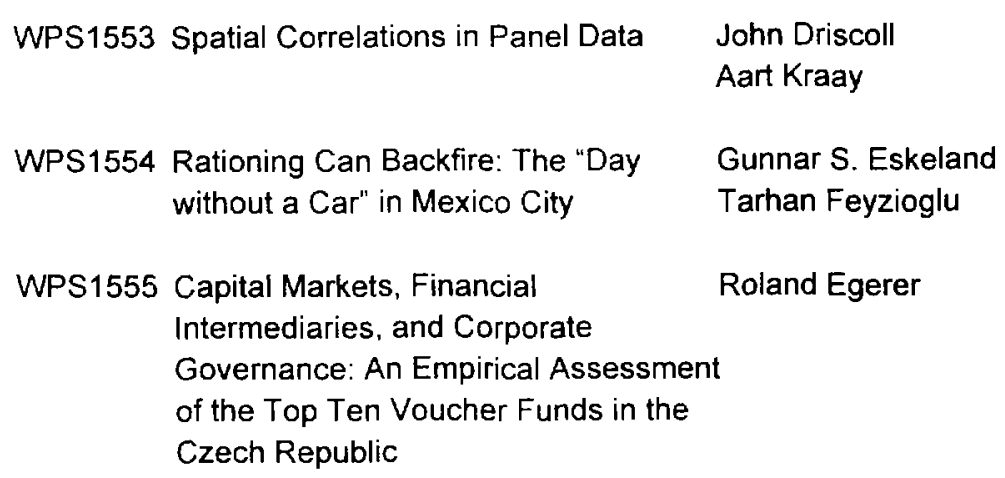$$
\text { John Driscoll }
$$$$
\text { Aart Kraay }
$$

Gunnar S. Eskeland$$
\text { Tarhan Feyzioglu }
$$$$
\text { Roland Egerer }
$$
the Effects on Energy Supply and the Investment Environment

Masayasu Ishiguro
Author Date

Christopher L. Gilbert

Jorge M. Rebelo

Pedro P. Benvenuto

Colin Thirtle

Robert Townsend

Johan van $Z y \mid$

Johan van Zyl

Hans Binswanger

Colin Thirtle

Jonathan Isham

Daniel Kaufman

Jonathan Isham

Daniel Kaufman

Lant Pritchett

Dimitri Vittas

Milan Vodopivec

$$
\text { Milan }
$$

November 1995

G. llogon 33732

November 1995

A. Turner 30933

November 1995

M. Williams

87297

November 1995

M. Williams 87297

November 1995

S. Torres 39012

November 1995

S. Fallon 38009

December 1995

P. Infante 37642

J. Walker 37466

December 1995

R. Martin 39065

December 1995

C. Bernardo 37699

December 1995 D. Brown 33542

December 1995

WDR 31393 December 1995

G. llogon 33732 


\section{Policy Research Working Paper Series}

\begin{tabular}{|c|c|c|c|c|}
\hline & Title & Author & Date & $\begin{array}{l}\text { Contact } \\
\text { for paper }\end{array}$ \\
\hline WPS1558 & $\begin{array}{l}\text { In Search of Price Rigidities } \\
\text { (Recent Sector Evidence from } \\
\text { Argentina }\end{array}$ & Jacques Morisset & December 1995 & $\begin{array}{l}\text { N. Cuellar } \\
37892\end{array}$ \\
\hline WPS1559 & $\begin{array}{l}\text { Have Transport Costs Contributed } \\
\text { to the Relative Decline of Sub- } \\
\text { Saharan African Exports? Some } \\
\text { Preliminary Empirical Evidence }\end{array}$ & $\begin{array}{l}\text { Azita Amjadi } \\
\text { Alexander J. Yeats }\end{array}$ & December 1995 & $\begin{array}{l}\text { S. Lipscomb } \\
33718\end{array}$ \\
\hline WPS1560 & Trade and Fluctuations & $\begin{array}{l}\text { Aart Kraay } \\
\text { Jaume Ventura }\end{array}$ & December 1995 & $\begin{array}{l}\text { R. Martin } \\
39065\end{array}$ \\
\hline WPS1561 & $\begin{array}{l}\text { Income Inequality and Aggregate } \\
\text { Saving: The Cross-Country Evidence }\end{array}$ & $\begin{array}{l}\text { Klaus Schmidt-Hebbel } \\
\text { Luis Servén }\end{array}$ & January 1996 & $\begin{array}{l}\text { E. Khine } \\
37471\end{array}$ \\
\hline WPS1562 & $\begin{array}{l}\text { Catching Up with Eastern Europe? } \\
\text { The European Union's Mediterranean } \\
\text { Free Trade Initiative }\end{array}$ & $\begin{array}{l}\text { Bernard Hoekman } \\
\text { Simeon Djankov }\end{array}$ & January 1996 & $\begin{array}{l}\text { F. Hatab } \\
35835\end{array}$ \\
\hline WPS1563 & $\begin{array}{l}\text { Equity and Growth in Developing } \\
\text { Countries: Old and New Pespectives } \\
\text { on the Policy Issues }\end{array}$ & $\begin{array}{l}\text { Michael Bruno } \\
\text { Martin Ravallion } \\
\text { Lyn Squire }\end{array}$ & January 1996 & $\begin{array}{l}\text { P. Sader } \\
33902\end{array}$ \\
\hline WPS1564 & $\begin{array}{l}\text { From Plan to Market: Patterns of } \\
\text { Transition }\end{array}$ & $\begin{array}{l}\text { Martha de Melo } \\
\text { Cevdet Denizer } \\
\text { Alan Gelb }\end{array}$ & January 1996 & $\begin{array}{l}\text { C. Rollison } \\
84768\end{array}$ \\
\hline WPS1565 & $\begin{array}{l}\text { Housing Finance in Transition } \\
\text { Economies: The Early Years in } \\
\text { Eastern Europe and the Former } \\
\text { Soviet Union }\end{array}$ & Bertrand Renaud & January 1996 & \\
\hline
\end{tabular}

